\author{
Abstract/Résumé analytique

\section{The Emergence of Concentrated Settlements in Medieval Western Europe: Explanatory Frameworks in the Historiography}

\author{
Daniel R. Curtis
}

\begin{abstract}
There is now a general scholarly consensus that the concentration of rural people into settlements in Western Europe (as opposed to dispersed or scattered habitations across the countryside) occurred in various stages between the eighth and twelfth centuries, though with regional divergences in precise timing, speed, formation, and intensity. What is clear from the literature is that a "one-size fits all" model for settlement development across Western Europe is not possible. Concentrated settlements appeared in certain parts of Europe for different reasons. This article discusses the strengths and limitations of four of the most influential frameworks for explaining patterns of medieval settlement concentration and their relation to social and economic change. The frameworks under analysis emphasize, respectively, power, coercion and lordship; communalism and territorial formalization; fieldsystems and resource-management; and urbanization and market-integration.
\end{abstract}

Il existe maintenant un consensus général érudit que la concentration des habitations en Europe occidentale (par opposition à des habitations dispersées et éparpillées dans les campagnes) se fit par diverses étapes entre le huitième et le douzième siècle, avec quand même des divergences régionales quant au moment précis, à la rapidité, la mise en place et l'intensité. Ce qu'on sait maintenant avec certitude, tirant une conclusion de la documentation, c'est que le modèle " taille unique » n'est pas possible lorsqu'on considère le développement des implantations en Europe de l'Ouest. Des agglomérations concentrées firent leur apparition dans certaines régions de l'Europe pour des raisons différentes les unes des autres. Dans cet article, nous examinons les mérites et les limites des quatre cadres les plus persuasifs qui expliquent les modes de concentration de ces implantations médiévales et leur rapport aux changements sociaux et économiques. Pour expliquer le processus de la concentration de ces habitations, ces cadres soulignent respectivement : le pouvoir, la contrainte et la seigneurie; la formalisation des territoires et communautés; la gestion des ressources et le système des champs; et, finalement, l'urbanisation et l'intégration des marchés. 


\section{THE EMERGENCE OF CONCENTRATED SETTLEMENTS IN MEDIEVAL WESTERN EUROPE: EXPANATORY FRAMEWORKS IN THE HISTORIOGRAPHY}

The collapse of the economic and political structures connected to the Western Roman Empire led to a population nadir in many parts of Western Europe by the sixth and seventh centuries. Although recent literature has warned against exaggerating the extent of this decline,${ }^{1}$ it is widely accepted that many regions experienced contraction in settlement in the centuries directly after the end of the Roman period. ${ }^{2}$ Land went out of cultivation and formerly wooded areas regained their trees. ${ }^{3}$ Many settlements were totally abandoned, ${ }^{4}$ including towns. ${ }^{5}$ Some scholars have noted for certain regions that a contracted and low-level population remained in place over a number of centuries - for example all the way up to the eleventh century in Northern Apulia in Southern Italy. ${ }^{6}$

${ }^{1}$ For example J. Moreland, "Transformations in a Sabine Landscape, 200-1000 A.D.," in P. Attema, A. Nijboer and A. Zifferero (eds.), Papers in Italian Archaeology. Communities and Settlements from the Neolithic to the Early Medieval Period (Oxford, 2005), VI, pp. 930-34; E. Louis, "A De-Romanised Landscape in Northern Gaul: The Scarpe Valley from the $4^{\text {th }}$ to the $9^{\text {th }}$ Century A.D.," in W. Bowden, L. Lavan, and C. Machado (eds.), Recent Research on the Late Antique Countryside (Leiden, 2004), p. 491. Also further east; L. Ellis, "Terra deserta: Population, Politics, and the [De]colonization of Dacia," World Archaeology, 30 (1998), pp. 220-37.

${ }^{2}$ See the almost apocalyptic description of the post-Roman countryside in Paul the Deacon (trans. W. Foulke), History of the Lombards (Philadelphia, 1907). On more general early-medieval restructuring of settlement after the Roman collapse, see R. Francovich, "Changing Structures of Settlements," in C. La Rocca (ed.), Short Oxford History of Italy: Italy in the Early Middle Ages (Oxford, 2002), pp. 144-67.

${ }^{3}$ C. Higounet, "Les forêts de 1'Europe occidentale du Ve siècle à 1'an mil," in XIII Settimana di Studi del Centro Italiano di Studi sull'Alto Medioevo (Spoleto, 1965), pp. 343-99; C. Wickham, "European Forests in the Early Middle Ages: Landscape and Land Clearance," in Land and Power: Studies in Italian and European Social history, 400-1200 (London, 1994), pp. 121-54.

${ }^{4}$ F. Cheyette, "The Origins of European Villages and the First European Expansion," Journal of Economic History, 37 (1977), pp. 195-97; G. Halsall, Settlement and Social Organization: The Merovingian Region of Metz (Cambridge, 2002 [1995]), pp. 212-13.

5 J-M. Martin, "Settlement and the Agrarian Economy," in G. Loud and A. Metcalfe (eds.), The Society of Norman Italy (Leiden, 2002), p. 18.

${ }^{6} \mathrm{G}$. Volpe, Contadini, pastori e mercanti nell'Apulia tardoantica (Bari, 1996); J-M. Martin, La pouillé du VI e XIII siècle (Rome, 1993). 
After the settlement decline connected to the demise of the Western Roman Empire, the view that is currently most widely disseminated is that the concentration of rural people into villages in Western Europe (as opposed to dispersed or scattered habitations across the countryside), occurred across various stages between the eighth and twelfth centuries. ${ }^{7}$ The shift in settlement to new, potentially more fertile sites, may have begun in earnest from 700 onwards. ${ }^{8}$ The actual chronology of this process varied according to region, with the formation of concentrated settlements beginning earlier in some areas of Western Europe and later in others. In some areas settlement concentration took the form of nucleated villages (people compacted around a main focal point). In other areas houses were laid out in a linear row perhaps along a dike, main street, or waterway, while elsewhere the concentration of habitation seemed to come together from multiple foci. ${ }^{9}$ It is important to note that this process did not necessarily predicate higher population densities in the concentrated settlement areas (in comparison to the dispersed or isolated settlement areas) but instead a rearrangement of the settlement structure. $^{10}$

The term "concentrated village" has been consciously avoided in this article, because there is still some debate as to what constitutes or defines a "village." $\mathrm{A}$ semantic debate, particularly among French historians and archaeologists, has been played out for some time. ${ }^{12}$ Indeed, some scholars such as Chris Dyer recognize that settlement concentration in England did occur before the classic "nucleation period" of the ninth to twelfth centuries, but still do not describe these AngloSaxon clusters as "villages" - in fact, he has explicitly used the term "non-villages."13 Similarly, Robert Fossier called these early-medieval settlements incomplete or "proto-villages." "In In contrast, other scholars such as Chris Wickham

${ }^{7}$ See the excellent H. Hamerow, Early Medieval Settlements: The Archaeology of Rural Communities in North-West Europe 400-900 (Oxford, 2002), pp. 121-24.

${ }^{8}$ C. Arnold and P. Wardle, "Early Medieval Settlement Patterns in England," Medieval Archaeology, 25 (1981), pp. 145-47; H. Hamerow, "Settlement Mobility and the 'Middle Saxon Shift': Rural Settlement and Settlement Patterns in Anglo-Saxon England," Anglo-Saxon England, 20 (1991), p. 1. Even earlier shifts have been suggested in H. Hamerow, "The Archaeology of Rural Settlement in Early Medieval Europe," Early Medieval Europe, 3 (1994), pp. 167-78.

${ }^{9}$ C. Taylor, "Polyfocal Settlement and the English Village", Medieval Archaeology, 21 (1977), pp. 189-93; "Aspects of Medieval Village Mobility in Medieval and Later Times," in S. Limbrey and J. Evans (eds.), The Effects of Man on the Landscape: The Lowland Zone (London, 1978), pp. 126-34.

${ }^{10}$ Some exceptionally high population densities were found in areas of highly dispersed settlement; see C. Wickham, "Settlement Problems in Early Medieval Italy: Lucca Territory," Archeologia Medievale, 5 (1978), pp. 495-503.

${ }^{11}$ A problem highlighted in E. Zadora-Rio, "Le village des historiens et le village des archéologiques," in E. Mornet (ed.), Campagnes médiévales: l'homme et son espace (Paris, 1995), pp. 145-53.

${ }^{12}$ P. Périn, "La part du Moyen Âge dans la genèse des terroirs de la France médiévale," in M. Parisse and X. Barral y Altet (eds.), Le roi de France et son royaume autour de l'an mil (Paris, 1992), pp. 225-34 ; J-M. Pesez, "Les naissances du village: position de la question," in Idem, pp. 223-4 ; R. Fossier, "La naissance du village," in Idem, pp. 219-22.

${ }^{13}$ C. Dyer, "Villages and Non-Villages in the Medieval Cotswolds," Transactions of the Bristol and Gloucestershire Archaeological Society, 120 (2002), pp. 11-35.

${ }^{14}$ R. Fossier, "Villages et villageois," in Villages et villageois au Moyen Age (Paris, 1992), pp. 207-14. 
do use the term "villages" for these earlier settlements - but more conceptually as a marker of the crystallization of local collective identity rather than of geography. ${ }^{15}$ In that sense, the definition of "concentrated settlement" used in this article is (deliberately) quite broad and is taken to mean the coming together of people residing in close geographical proximity to one another. "Concentrated settlement" in this paper takes in all degrees of concentration: from those large villages which were rigidly planned and systematically ordered to loose informal clusterings of people around a small focal point on the other.

Historians and archaeologists have long been interested in explaining the process of settlement concentration. What is clear from the literature is that a "onesize fits all" model for settlement development across Western Europe is not possible. Concentrated settlements appeared in certain parts of Europe for different reasons. Not only were the chronologies highly divergent but sometimes the actors or agents of settlement change were different. While for some areas scholars have emphasized the role of elites such as manorial lords in instigating the concentration of habitation, others have seen the development "from below" by asserting the capacity of rural peasants to initiate the process themselves. ${ }^{16}$ Nonetheless, while it is clear that there is no one explanatory model for the whole of Western Europe, a number of thematically and conceptually coherent explanatory frameworks can be discerned from the historiography. This article discusses the four most influential ones, highlighting how each helps us to better understand social and economic change in the medieval period, while also pointing out their limitations or inconsistencies. They are classified according to their main areas of emphasis: (i) power, coercion, and lordship; (ii) communalism and territorial formalization; (iii) fieldsystems and resource-management; and (iv) urbanization and market-integration.

\section{Power, Coercion, and Lordship}

One way in which the concentration of rural settlement has been framed is through the lens of applied power and coercion. There are a number of key facets to this kind of explanatory framework. First of all, in terms of "agents of settlement change," this model gives more precedence to "elite" members of medieval society and emphasizes the impact of powerful lords or ecclesiastical institutions in moving people into concentrations. Second, in terms of timing, this framework often gives more precedence to the high Middle Ages, since this was the period when the classic system of localized feudal lordships crystallized across most parts of Western Europe. Third, with regard to the dynamism and speed of the settlement

${ }^{15} \mathrm{C}$. Wickham, Framing the Early Middle Ages: Europe and the Meditteranean, 400-800 (Oxford, 2005), p. 517.

${ }^{16}$ An issue discussed in P. Harvey, "Initiative and Authority in Settlement Change," in M. Aston, D. Austin, and C. Dyer (eds.), The Rural Settlements of Medieval England: Studies Dedicated to Maurice Beresford and John Hurst (Oxford, 1989), p. 43; C. Dyer, "Power and Conflict in the Medieval English Village," in D. Hooke (ed.), Medieval Villages: A Review of Current Work (Oxford, 1985), p. 32. 
concentration process, this framework is prone to seeing rapid and intense changes in the settlement structure - perhaps as testaments to the "sweeping" or radical changes imposed by powerful elites.

In this type of explanatory framework, elite interest groups such as manorial or seigneurial lords used their (often extra-economic) power to stimulate the movement of populations into rural centres. A famous example of this kind of approach is the vast literature now compiled on incastellamento, which occurred roughly between the tenth and twelfth centuries in various parts of Western Europe. ${ }^{17}$ Essentially incastellamento was a process of castle building, but the term also refers generally to the fortification of habitation. According to the theory, in seeking to dominate the countryside, express their power and jurisdiction, and confirm their extra-economic privileges, seigneurial lords forced communities into concentrated settlements; often with the castle or fortified manor house as the focus point, and sometimes with the inhabitants residing within the settlement walls. As a result, this theory fits into the wider story of territorial crystallization in the high Middle Ages with the formalization of seigneurialism and local lordships. ${ }^{18}$ As the old larger Carolingian estates broke up in the tenth century, a patchwork of lordships and manors emerged in their place, often (though not always) exploiting demesnes using serf labour. ${ }^{19}$ The formalization of local seigneurial territories prefigured the appearance of rural communes in many places, as local solidarities slowly crystallized around physical or conceptual nuclei - the manor, the castle, or even the local church..$^{20}$ Thus, the concentration of settlement did not always result from the power of the signoria itself, but was more attributable to the growing sense of coherence and local identity of the inhabitants of the formalized territory focused on seigneurial centres. ${ }^{21}$ Furthermore, by placing so much emphasis on the feudal revolution, this framework has led some scholars to assume (perhaps incorrectly) that much of the early medieval landscape was characterized by scattered settle-

${ }^{17}$ A literature stimulated in the first instance by the classic P. Toubert, Les structures du Latium médiéval: le Latium méridional et la Sabine du IX siècle (Rome, 1973), I-II. For Toubert's influence and the mass of literature on incastellamento that it stimulated, see the historiography offered in E. Hubert, "L'incastellamento dans le Latium: remarques à propos de fouilles récentes," Annales. Histoire, Sciences Sociales, 55 (2000), pp. 583-99.

${ }^{18}$ The best literature on this topic is S. Reynolds, Kingdoms and Communities in Western Europe, 900-1300 (Oxford, 1997), esp. pp. 101-54; R. Fossier, "Rural Economy and Country Life," in T. Reuter (ed.), The New Cambridge Medieval History, c. 900-c. 1024 (Cambridge, 2000), III, pp. 27-63; T. Bisson, "The Feudal Revolution," Past and Present, 142 (1994), pp. 6-42; C. Wickham, "Debate. The Feudal Revolution," Past and Present, 155 (1997), pp. 196-208.

${ }^{19}$ A. Verhulst, "Economic Organization," in R. McKitterick (ed.), The New Cambridge Medieval History, c. 700-c. 900 (Cambridge, 1995), II, pp. 495-97.

${ }^{20}$ Described as "encellulement" in Fossier, "Villages et villageois." Idea originally conceived by Fossier, La terre et les hommes en Picardie jusqu'à la fin du XIIIe siècle (Amiens, 1990).

${ }^{21} \mathrm{C}$. Wickham, The Mountains and the City: The Tuscan Apennines in the Early Middle Ages (Oxford, 1988), p. 339. 
ment. ${ }^{22}$ Some have even explicitly stated that "villages" only appeared in Europe from around CE 1000 onwards. $^{23}$

Particularly in France, Spain, and Italy, the link between the castle, the concentrated settlement, and the expression of power and authority is very strong in the historiography. One of the recurring themes is the rise of territorial lords such as dukes, barons and counts vis-à-vis the declining influence of a central authority. ${ }^{24}$ In Northern Italy, the castles initially spread through the tenth and eleventh centuries and became the seats of territorial lords or very powerful feudal families. ${ }^{25}$ After this initial development, a second phase of castle-building by local seigneurial lords began, ${ }^{26}$ often with very ordered and regular arrangement of housing. ${ }^{27}$ Similarly in the centre of the Iberian Peninsula (which later in the 1200 s became known as Castile), castles spread quickly in the tenth century through the growing influence of powerful counts. In Catalonia, concentrated sites initially crystallized around churches - the context of conflict between competing secular and ecclesiastical jurisdictions. ${ }^{28}$ They also emerged around pre-existing castles. ${ }^{29}$ Later, entirely new fortified villages were created (vilanoves) by counts or lords in the eleventh to thirteenth centuries, ${ }^{30}$ although many castles were built without creating changes in the settlement pattern. ${ }^{31}$ A number of existing settlements were

${ }^{22}$ M. Montanari, L'alimentazione contadina nell'alto medioevo (Naples, 1979), pp. 65-70; B. Andreolli and M. Montanari, L'azienda curtense in Italia: proprièta della terra e lavoro contadino nei secoli VIII-XI (Bologna, 1985), pp. 177-200.

${ }^{23}$ J. Chapelot and R. Fossier, Le village et la maison au Moyen Age (Paris, 1980).

${ }^{24}$ See C. Wickham, Early Medieval Italy: Central Power and Local Society, 400-1000 (London, 1989).

${ }^{25}$ P. Toubert, Dalla terra ai castelli. Paesaggi, agricoltura e poteri nell'Italia medievale (Turin, 1997); A. Settia, Castelli e villaggi dell'Italia padana: popolamento, potere e sicurezza fra IX e XIII secolo (Naples, 1984); D. Andrews, “Castelli e incastellamento nell'Italia centrale," in R. Comba (ed.) Castelli storia e archeologia (Cuneo, 1981), pp. 123-36; C. Molducci, "L'incastellamento dei conti Guidi nel Valdarno superiore fra X e XII secolo," in G. Vannini (ed.), Rocca Ricciarda, dai Guidi ai Ricasoli. Storia e archeologia di un castrum medievale nel Pratomagno aretino (Florence, 2009), pp. 53-69.

${ }^{26}$ M. Cortese, "L'incastellamento nel territorio di Arezzo (secoli X-XII)," in R. Francovich and M. Ginatempo (eds.) Castelli. Storia e archeologia del potere nella Toscana medievale (Florence, 2002), pp. 67-109.

${ }^{27}$ R. Farinelli and A. Giorgi, "Fenomeni di accentramento insediativi nella Toscana meridionale tra XII e XIII secolo: il 'secondo incastellamento' in area senese," in Francovich and Ginatempo (eds.), Castelli, pp. 239-84.

${ }^{28}$ M. Riu, "El paper dels 'castra' en la redistribució de l'hàbitat al Comtat d'Osona," Ausa, 10 (1982), p. 402.

${ }^{29} \mathrm{~J}$. Bolòs, Els Orígens Medievals del Paisatge Català. L'arqueologia del paisatge com a font per a conèixer la historia de Catalunya (Barcelona, 2004), pp. 203-19.

${ }^{30} \mathrm{~J}$. Bolòs, "Landscape Formation in a Mediterranean Country of the Middle Ages. Changes and Continuity in Catalonia between the $6^{\text {th }}$ and the $15^{\text {th }}$ Century," Landscape History, 30 (2009), p. 31; "Changes and Survival: The Territory of Lleida (Catalonia) after the Twelfth-Century Conquest," Journal of Medieval History, 27 (2001), p. 232; L. Bayrou and G. Castellvi, "Esquisse d'une étude des vestiges des fortifications urbaines médiévales en Roussillon," in Estudis Rossellonesos dedicats a en Pere Ponsich (Perpignan, 1987), pp. 187-22.

${ }^{31}$ P. Freedman, The Origins of Peasant Servitude in Medieval Catalonia (Cambridge, 2004), p. 30. 
abandoned in order to move into the seigneurial concentrations. ${ }^{32}$ In some places, high levels of chronological precision have been offered: scholars have situated the main move towards incastellamento in the Abruzzo of Italy and the Massif Central of France in the fifty-year period between 970 and $1020 .{ }^{33}$ In some places, incastellamento and settlement concentration took off slightly later than the eleventh century; this was the case for Aquitane in southwest France. ${ }^{34}$ Although it has been suggested that in southern Italy, incastellamento was most pronounced in those areas dominated by great landowning monasteries such as Montecassino, which wanted to create new settlements for territorial control and protection, ${ }^{35}$ Graham Loud cautioned against over-exaggerating this development. ${ }^{36}$ It is clear that monasteries such as San Vincenzo did use fortified settlements as a symbol of their territorial claim to property under pressure from the Counts of Isernia, ${ }^{37}$ and that some monasteries such as Montevergine coerced rural producers into concentrations through harsh sharecropping contracts, ${ }^{38}$ yet the process of creating fortified settlements was to be found in many places across southern Italy (especially after the Norman invasion) where aristocrats were consolidating their power to the detriment of princely authority. ${ }^{39}$ Monasteries were thus important, but not the only or even the main forces promoting incastellamento.

It was perfectly possible, however, to see concentrated settlements and dominant lords without castles. ${ }^{40}$ In many works we see reference to a so-called "landscape of lordship," whereby seigneurial lords would place their manor houses in a central location and then carefully lay out standardized plots for their tenants so

32 J. Bolòs, "El territori i els seus límits. El poble, la parròquia i el castell a l'edat mitjana," in Territori i societat a l'edat mitjana (Lleida, 1987), I, p. 81; E. Martí, "Vilanova de la Barca (Segrià): organització del territori abans i després de l'an 1212," in Territori i societat a l'edat mitjana (Lleida, 2000), III, pp. 351-77.

${ }^{33}$ L. Feller, "Pouvoir et société dans les Abruzzes autour l'an mil: aristocratie, incastellamento, appropriation des justices (960-1035)," Bullettino dell'Istituto Storico Italiano per il Medioevo, 94 (1988), pp. 1-72; Les Abruzzes médiévales. Territoire, économie et société en Italie centrale du IXe au XIIe siècle (Rome, 1998), pp. 213-87; C. Lauranson-Rosaz, L'Auvergne et ses marges (Velay, Gevaudan) du VIIIe au XIe siècle: la fin du monde antique? (Le Puy-en-Velay, 1987), p. 371.

${ }^{34}$ C. Higounet, "Structures sociales, 'castra' et castelnaux dans le Sud-Ouest aquitain (xe-xiiie siècles)," in Structures féodales et féodalisme dans l'Occident méditerranéen (Xe-XIIle siècles) (Rome, 1980), pp. 109-17.

${ }^{35}$ B. Kreutz, Before the Normans: Southern Italy in the Ninth and Tenth Centuries (Philadelphia, 1991), pp. 134-35.

${ }^{36}$ G. Loud, "Southern Italy in the Tenth Century," in T. Reuter (ed.), The New Cambridge Medieval History, c.900-c.1024 (Cambridge, 1999), III, p. 640.

${ }^{37} \mathrm{C}$. Wickham, Il problema dell'incastellamento nell 'Italia centrale: l'esempio di San Vincenzo al Volturno (Florence, 1985), pp. 30-33.

${ }^{38}$ A. Tallarico, “L'Abbazia di Montevergine nell'età normanna: formazione e sviluppo di una potenza economica e politica," Samnium, 45 (1972), p. 219.

${ }^{39}$ G. Loud, The Latin Church in Norman Italy (Cambridge, 2007), p. 30.

${ }^{40}$ M. Durany Castrillo, San Pedro de Montes: El dominio de un monasterio benedictino en El Bierzo (Léon, 1976), pp. 95-105. 
that they would be close at hand to provide labour on the demesnes as needed. ${ }^{41}$ Noting the close correlation between high levels of manorialization and the proliferation of large villages in the "champion lands" of Central England, ${ }^{42}$ scholars have long seen the manor as the driving force behind the concentration of settlements. It must be said, however, that the concentration of settlement was not always concurrent with the emergence of formalised seigneurialism. In the Central Dutch River Area, concentrated settlements actually emerged in the Merovingian period when the very earliest manorial curtes were set down. ${ }^{43}$ When the manorial system broke down in the late thirteenth century in some parts of this region, certain settlements experienced strong collapses with the abandonment of farms. ${ }^{44}$ Scholars such as Jean-Pierre Devroey and Georges Despy, moreover, have shown that, although the manorial mode of economic exploitation and organization was important in crystallising clustered habitation, this process was already taking place in the late eighth and ninth centuries. ${ }^{45}$

Although applicable in certain parts of Western Europe, the power and coercion framework for explaining the concentration of medieval settlements has some inconsistencies and limitations, as scholars have become increasingly aware. Chris Wickham was one of the first to question explicitly the incastellamento thesis, noting in a region of Tuscany how the proliferation of fortified structures and an intense phase of castle building in the eleventh and twelfth centuries had no profound effects on demographic or settlement trends. ${ }^{46}$ Aristocrats built castles, but these ended up simply being isolated additions to an already dispersed pattern of settlement. Weak control of the territories and fragmented jurisdictions held by a number of overlapping lordships prevented any one lord from coercing inhabitants into

${ }^{41}$ A. Castagnetti, L'organizzazione del territorio rurale nel Medioevo (Turin, 1979), esp. p. 224; R. Faith, The English Peasantry and the Growth of Lordship (Leicester, 1997); P. Harvey, A Medieval Oxfordshire Village: Cuxham, 1240 to 1400 (London, 1965).

${ }^{42}$ An excellent series of maps show this in B. Roberts and S. Wrathmell, An Atlas of Rural Settlement in England (Swindon, 2000), pp. 2, 5, 15; Region and Place: A Study of English Rural Settlement (London, 2002), pp. 1-10.

${ }^{43}$ E. Bult and D. Hallewas, "Archaeological Evidence for the Early-Medieval Settlement around the Meuse and Rhine Deltas up to ca. AD 1000," in J. Besteman, J. Bos and H. Heidinga (eds.), Medieval Archaeology in the Netherlands. Studies Presented to H.H. van Regeteren Altena (Assen, 1990), pp. 71-90; B. van Bavel, Transitie en continuïteit: de bezitsverhoudingen en de plattelandseconomie in het westelijke gedeelte van Gelderse rivierengebied, ca. 1300 - ca. 1570 (Hilversum, 1999), pp. 5361.

${ }^{44}$ J. Oudhof, "Sporen en structuren," in J. Oudhof, J. Dijkstra and A. Verhoeven (eds.), “Huis Malburg" van spoor tot spoor. Een middeleeuwse nederzetting in Kerk-Avezaath (Amersfoort 2000) 45-77; J. van Doesburg and P. Schut, Die hofstat tot Zoelen, daer dat hues op plach te staen - Een waarderend booronderzoek op de motte Aldenhaag (gemeente Buren, Gelderland) (Amersfoort 2007).

${ }^{45}$ G. Despy, "Villes et campagnes aux IX e Xe siècles. L'exemple du pays mosan," Revue du Nord, 50 (1968), pp. 145-68; J. Devroey, "Mansi absi: indices de crise ou de croissance de l'économie rurale du haut Moyen Age?" Le Moyen Age, 82 (1976), pp. 97-118.

${ }^{46}$ Wickham, Mountains and the City, p. 300. Also see Ibid, "Settlement Patterns in Medieval Italy: (1) Nucleation (Monte Amiata in Southern Tuscany); (2) Dispersal (the Casentino in Northern Tuscany)," in A. Mackay (ed.), Atlas of Medieval Europe (London, 1997), pp. 140-41. 
new villages. ${ }^{47}$ Following on from this, there now has been a trend in the rural histories of medieval France that shows that the process of castle building did nothing to change the existing settlement patterns. ${ }^{48}$ In many parts of Portugal (except the north-west), castles had no further impact for the arrangement of settlement. ${ }^{49}$ In Campania in Southern Italy, Graham Loud has similarly noted how Norman castles were not always principle foci for settlement, ${ }^{50}$ with Laurent Feller making equivalent comments for the Abruzzo. ${ }^{51}$ And although the formalization of seigneurialism over roughly the tenth to twelfth centuries has grounded many explanations for concentrated settlement formation in the Middle Ages, some scholars (particularly from Italy) have also suggested that the same process may just as easily have led to the emergence of fortified isolated habitations during that period. ${ }^{52}$

Furthermore, an increasing amount of literature has now shown that concentrated settlements with a fortified character began to appear much earlier in the medieval period, before the so-called "feudal revolution." In particular, much has been written on the formation of hilltop villages from as early as the eighth century in parts of Central Italy and Northwestern Spain, ${ }^{53}$ even if the fortifications them-

${ }^{47}$ A feature noted elsewhere in Italy; Settia, Castelli e villaggi, pp. 258-68.

${ }^{48}$ B. Phalip, Seigneurs et bâtisseurs. La château et l'habitat seigneurial en Haute-Auvergne et Brivadois entre le XIe et le XV siècle (Clermont-Ferrand, 1993); J-L. Boudartchouk, Le Cardalez de l'antiquité au XIII siècle: terroirs, hommes et pouvoirs (Lille, 1998); P-Y. Laffont, Châteaux du Vivarais. Pouvoirs et peuplement en France méridionale du haut Moyen Age au XIIle siècle (Rennes, 2010); D. Istria, Châteaux et habitats fortifiés dans le nord de la Corse (1077-1358) (Marseilles, 2000); D. Mouton, "La roca de Niozelles et les mottes castrales du bassin de la Durance moyenne et ses abords" (PhD diss., L'Université Aix-Marseille, 2000); F. Boutoulle, "La société laique en Bordelais et Bazadais (1075-1225)" (PhD diss., L’Université Aix-Marseille, 2001).

${ }^{49}$ R. Durand, "Villages et seigneurie au Portugal (xe-xiiie s)," Cahiers de Civilisation Médiévale, 30 (1987), pp. 205-11.

${ }^{50}$ G. Loud, "Continuity and Change in Norman Italy: The Campania during the Eleventh and Twelfth Centuries," Journal of Medieval History, 22 (1996), p. 322.

${ }^{51}$ L. Feller, "L'incastellamento inachevé des Abruzzes," in R. Francovich and M. Milanese (eds.), Lo scavo archeologico di Montarrenti e i problemi dell'incastellamento medievale. Esperienze e confronto (Florence, 1990), pp. 121-36.

${ }^{52} \mathrm{R}$. Comba, "La dispersione dell'habitat nell'Italia centro-settentrionale tra XII e XV secolo. Vent'anni di ricerche," Studi Storici, 25 (1984), pp. 765-83; "Le origini medievali dell'assetto insediativo moderno nelle campagne italiane," in Storia d'Italia. Annali (Turin, 1985), VIII, p. 386; A. Settia, "Tra azienda agricola e fortezza: case forti, motte, e tombe nell'Italia settentrionale. Dati e problemi," Archeologia Medievale, 7 (1980), pp. 31-54; "L'esportazione di un modello urbano: torri e case forti nelle campagne del nord Italia," Società e Storia, 12 (1981), pp. 273-97; "Lo sviluppo di un modello: origine e funzioni delle torri private urbane nell'Italia centro-settentrionale," in Paesaggi urbani dell'Italia padana nei secoli VIII-XIV (Bologna, 1988), pp. 157-71; E. Saracco Previdi, "Grange cistercensi nel territorio maceratese: insediamenti rurali monastici dei secoli XII e XIII," Proposte e Ricerche, 7 (1981), pp. 16, 22.

${ }^{53}$ R. Francovich, "The Beginning of Hilltop Villages in Early Medieval Tuscany,” in J. Davis and M. McCormick (eds.), The Long Morning of Medieval Europe: New Directions in Early Medieval Studies (London, 1998), pp. 55-82; "L'incastellamento e prima dell'incastellamento," in M. Barceló and P. Toubert (eds.) L'incastellamento (Rome, 1998), pp. 13-20; M. Valenti, L'insediamento altomedievale nelle campagne Toscane: paesaggi, popolamento e villaggi tra VI e X secolo (Florence, 2004); "Villaggi e comunità nella Toscana tra VII e X secolo: la ricerca archeologica," in P. Galetti (ed.), Edilizia residenziale tra IX e X secolo: storia e archeologia (Florence, 2010), p. 62; R. Francovich and R. 
selves were modest. ${ }^{54}$ Much of this work is connected to archaeological studies which, in order to understand hierarchies of settlement, have examined the landscape for the evidence of the expression of power relations. In one famous excavation project, archaeologists researching the hilltop site of Montarrenti near Siena, in Tuscany, have demonstrated that even as early as the eighth century, settlements were being rearranged and reordered according to hierarchies of power. ${ }^{55}$ The higher status, aristocratic complex was situated at the top of the hill, while the lower status buildings of the community were strewn across the winding slopes of the hillside, continuing down to the bottom. Similar signs of social differentiation have been found for Scarlino and Poggibonsi in the ninth century. ${ }^{56}$

To summarize, then, a basic point is that concentrated settlements were emerging even before the formalisation of seigneurialism of the high Middle Ages. As Chris Wickham has argued by asserting the importance of a decline in Roman taxation and increase in the freedom of the peasant rustici, signs of clustered settlement formation appear as early as the seventh century, ${ }^{57}$ although admittedly Wickham's methodology has recently come under scrutiny from Mario Costambeys, who takes issue with the way certain terms from the manuscript sources such as "vicus" have been interpreted. ${ }^{58}$ Nevertheless, concentrated early-medieval settlements have been identified all across Southern France, ${ }^{59}$ not only on hilltops, but also on plains and flatlands. ${ }^{60}$ Moreover, fortified concentrations were present at least by the ninth century on both hill tops and sand dunes (in swampy areas) across large parts of Central Europe - particularly within the territory of the "Great Moravian Empire" including regions of what are today the Czech Republic,

Hodges, Villa to Village (London, 2003), pp. 61-74; I. Martín Viso, "Central Places and the Territorial Organization of Communities: The Occupation of Hilltop Sites in Early Medieval Northern Castile," in W. Davies, G. Halsall and A. Reynolds (eds.), People and Space in the Middle Ages, 300-1300 (Turnhout, 2006), p. 176; J. Antonio Quirós Castillo, "Cambios y transformaciones en el paisaje el Apenino toscano entre la Antigüedad Tardía y la Edad Media. El castaño,” Archeologia Medievale, 25 (1998), pp. 177-98.

${ }^{54}$ A. Cagnana, "Le strutture del castello," in T. Mannoni and G. Murialdo (eds.), S. Antonino: un insediamento fortificato nella Liguria bizantina (Bordighera, 2001), pp. 101-17.

${ }^{55}$ F. Cantini, Il castello di Montarrenti. Lo scavo archeologico (1982-1987). Per la storia della formazione del villagio medievale in Toscana (sec. VII-XV) (Florence, 2003); R. Francovich and R. Hodges, "Archeologia e storia del villaggio fortificato di Montarrenti (SI): un caso o un modello?" Archeologia Medievale, 16 (1989), pp. 22-38; G. Barker et al., "The Montarrenti Survey, 1985: Integrating Archaeological, Environmental, and Historical Fata," Archeologia Medievale, 13 (1986), pp. 291-329.

${ }^{56}$ M. Valenti, Poggio imperiale a Poggibonsi: dal villaggio di capanne al castello di pietra (Florence, 1996); R. Francovich, Scarlino I: storia e territorio (Florence, 1993).

${ }^{57}$ Wickham, Framing the Early Middle Ages, pp. 514-18.

${ }^{58}$ M. Costambeys, "Settlement, Taxation and the Condition of the Peasantry in Post-Roman Central Italy," Journal of Agrarian Change, 9 (2009), pp. 92-119.

${ }^{59}$ E. Zadoro-Rio, "Early Medieval Villages and Estate Centres in France (c.300-1100)," in J. Antonio Quirós Castillo (ed.), The Archaeology of Early Medieval Villages in Europe (Bilbao, 2009), pp. 77-98.

${ }^{60}$ E. Peytremann, Archéologie de l'habitat rural dans le nord de la France du IVe au XIIe siècle (Saint-Germain-en-Laye, 2003), I, pp. 319-30; A. Nice, "Goudelancourt-les-Pierrepont, Le Fossé StMartin,” Bulletin Scientifique Régional de Picardie, I-II (1998), pp. 27-28. 
Austria, and Slovakia. ${ }^{61}$ Occasionally, concentrations had already been developed and deserted by the eighth century. ${ }^{62}$ In Drenthe, in the north-eastern part of the Low Countries, settlement concentrations from the seventh and eighth centuries have been identified ${ }^{63}$ while in Apulia in Southern Italy, extensive excavations of former Roman villas have shown that far from disappearing entirely after the collapse of the Western Roman Empire, many of these isolated elite structures were remodelled between the sixth and ninth centuries into concentrated clusters of peasant producers ${ }^{64}$ Indeed, it is now well known that isolated habitations could incorporate new farmsteads by splitting existing land units through heirs. ${ }^{65}$ Furthermore, the incastellamento or encellulement thesis of the 80 s and 90 s seemed to suggest that the new concentrated villages of the high Middle Ages necessitated abandonment of early-medieval dispersed sites — yet Spanish archaeology has now questioned that wisdom, highlighting the difficulty in turning up any physical evidence to support the case. ${ }^{66}$

In that sense, the interpretive framework that places power and coercion at its centre, remains important and influential in explanations of medieval village concentration, though, thanks to new trends in archaeology, it has now broken free of the restrictive confines of the incastellamento thesis and the classic period of formalized seigneurialism. Scholars are still sure that the concept of power is important for our understanding of medieval settlement development, but increasingly we are seeing more and more links between the expression of power and moves towards settlement concentration occurring before the tenth and eleventh centuries. It is a matter of semantics whether we decide to call these earlier concentrations "villages," though in more recent years there has been a greater tendency to do so.

${ }^{61}$ H. Herold, "Fortified Settlements of the $9^{\text {th }}$ and $10^{\text {th }}$ Centuries AD in Central Europe: Structure, Function and Symbolism," Medieval Archaeology, 56 (2012), pp. 60-84.

${ }^{62}$ T. Potter, "Excavations in Mazzano Romano," Papers of the British School at Rome, 40 (1972), pp. 135-45; A. Schäfer, "Die Wüstung Zimmern auf Gemarkung Stebbach," Oberrheinische Studien, 1 (1970), pp. 357-74.

${ }^{63} \mathrm{H}$. Waterbolk, "Patterns of the Peasant Landscape," Proceedings of the Prehistoric Society, 61 (1995), pp. 17-21.

${ }^{64}$ G. Volpe, R. De Venuto, R. Goffredo and M. Turchiano, "L'abitato altomedievale di Faragola (Ascoli Satriano)," in G. Volpe and P. Favia (eds.), V Congresso Nazionale di Archaeologia Medievale (Florence, 2009), pp. 284-90; G. Volpe, G. De Felice and M. Turchiano, "Faragola (Ascoli Satriano). Una residenza aristocratica tardoantica e un villaggio altomedievale nella Valle del Carapelle: primi dati," in G. Volpe and M. Turchiano (eds.), Faragola 1. Un insediamento rurale nella Valle del Carapelle. Ricerche e studi (2010), pp. 25-56; P. Favia, "Temi, approcci, metodologici, modalità e problematiche della ricerca archeologica in un paesaggio di pianura di età medievale: il caso del Tavoliere di Puglia," in N. Mancassola and F. Saggioro (eds.), Medioevo, paesaggi e metodi (Mantua, 2006), pp. $179-98$.

${ }^{65}$ S. Turner and R. Wilson-North, "South-West England: Rural Settlements in the Middle Ages," in N. Christie and P. Stamper (eds.), Medieval Rural Settlement: Britain and Ireland, AD 800-1600 (Oxford 2012), p. 144.

${ }^{66}$ J. Antonio Quirós Castillo, "Las aldeas de los historiadores y de los arqueólogos en la Alta Edad Media del norte peninsular," Revista de Estudios Medievales, 2 (2007), pp. 65-86. Admittedly there are methodological difficulties with recovering material for dispersed settlements as higlighted in S. Stoddart, "Un periodo oscuro nel Casentino: la validità dell'evidenza negativa," Atti e Memorie della Accademia Petrarca di Lettere Arti e Scienze, 43 (1979-80), pp. 197-232. 


\section{Communalism and Territorial Formalization}

In contrast to the power and coercion framework, some scholars have suggested that the most important historical processes shaping medieval settlement patterns in Western Europe came from new institutional configurations from below. ${ }^{67}$ This kind of explanatory framework has a number of key facets. First, in terms of "agents of settlement change," this model assigns those lower down the social hierarchy a more active role in stimulating concentrated forms of habitation, emphasizing the capacity of farmers, peasants, tenants, labourers, and commoners to negotiate and cooperate with each other, and to engage in dialogues with "elites" in order to rearrange settlements. Second, as with the power and coercion framework, this model highlights the high and late Middle Ages as key developmental periods, partly because it was around this time across many areas of Western Europe that significant local laws, rules, and customs were written down and formalized institutionally. Third, with regard to dynamism and speed in the settlement concentration process, this framework does not tend to cast the emergence of concentrations as a rapid or intense "event," assessing it rather as a process that developed organically and perhaps incrementally over a long term.

According to this theory, the need to regulate resources more effectively at the local level acted as a cohesive force that promoted habitation around central sites. So, for example, one study has linked the formalization of the village community (and in turn its physical crystallization) with the emergence of a more formally regulated silvo-pastoral economy and grazing rights. ${ }^{68}$ Other works on settlements in the Low Countries have also linked concentration with the need for collective water management, and for the protection that self-government provided for administration, justice, and taxation. Bas van Bavel depicts a situation where

$\ldots$ the increasing nucleation of settlement - with scattered
farmsteads being rearranged into villages — and the growing
density of population, both compelled and enabled villagers to
work more closely together, particularly in coordinating agricul-
tural activities and regulating access to ever scarcer resources. ${ }^{69}$

In medieval Holland, village communities often overlapped with water board organizations. ${ }^{70}$ This point must be nuanced against work from scholars such as Chris

${ }^{67}$ P. Blickle, Kommunalismus. Skizzen einer gesellschaftlichen Organisationsform. Band 2: Europa (Munich, 2000); From the Communal Reformation to the Revolution of the Common Man (Leiden, 1998), esp. p. 12; T. De Moor, "The Silent Revolution: A New Perspective on the Emergence of Commons, Guilds, and other Forms of Corporate Collective Action in Western Europe," International Review of Social History, 53 (2008), pp. 179-212.

${ }^{68}$ G. Sivéry, Structures agraires et vie rurale dans le Hainaut a la fin du Moyen-Age (Lille, 1977), pp. 275-92.

${ }^{69}$ B. van Bavel, Manors and Markets: Economy and Society in the Low Countries, 500-1600 (Oxford, 2010), p. 93.

${ }^{70}$ H. van der Linden, Recht en territoir: een rechtshistorisch-sociografische verkenning (Assen, 1972), pp. 10-26. 
Wickham, however, who have shown that the formalization of the rural commune could just as easily have co-existed with highly dispersed settlement patterns. ${ }^{71}$

In the Northern part of the Low Countries in Groningen and Friesland, communal concerns over the dangers of flooding stimulated groups of people to build and group their houses together on large mounds known as terpen. ${ }^{72}$ Further inland, in Drenthe and the Gooi, the marken or meenten (the commons) developed in close association with the crystallization of small concentrated villages. ${ }^{73}$ Participants in the collective system for regulating resources frequently resided around a small central space (like a village green) known as a brink. ${ }^{74}$ Similar developments occurred in the medieval Campine region of Brabant, where as a result of a rivalry between the Duke of Brabant and local seigneurial lords, both parties ended up granting privileges in order to attract immigrants to their territories. ${ }^{75} \mathrm{New}$ small concentrated villages and hamlets emerged, particularly in the thirteenth century, ${ }^{76}$ where the communities displayed secure property rights and powerful village governments capable of maintaining the commons over long periods through conflict resolution..$^{77}$

Aside from the focus on the rural commune, other more "bottom-up" interpretations of settlement concentration in medieval Europe have been offered, where the capacity for "ordinary" peasants or tenants to organize themselves was dictated by the levels of freedom and autonomy they experienced. These kinds of settlements were often developed in the twelfth and thirteenth centuries, on the crest of widespread increases in population across Western Europe, and were based

${ }^{71}$ C. Wickham, Community and Clientele in Twelfth-Century Tuscany: The Origins of the Rural Commune in the Plain of Lucca (Oxford, 1998).

${ }^{72}$ M. Bierma, A. Clason, E. Kramer and G. de Langen (eds.), Terpen en wierden in het FriesGroningse kustgebied (Groningen 1988).

${ }^{73}$ J.L. van Zanden, "The Paradox of the Marks. The Exploitation of the Commons in the Eastern Netherlands, 1250-1850," Agricultural History Review, 47 (1999), pp. 125-45; A. Kos, Van meenten tot marken. Een onderzoek naar de oorsprong en ontwikkeling van de Gooise marken en de gebruiksrechten op de gemene gronden van de Gooise markegenoten (1280-1568) (Hilversum, 2010). I-II.

${ }^{74}$ T. Spek, Het Drentse esdorpenlandschap. Een historisch-geografische studie (Utrecht, 2004),

${ }^{75}$ A. De Wachter, "De opname van de Kempen in het hertogdom Brabant (elfde tot dertiendeveertiende eeuw). Een politiek-geografische probleemstelling," Tijdschrift van de Belgische Vereniging voor Aardrijkskundige Studies, 68 (1999), pp. 111-40; W. Steurs, "Seigneuries et franchises dans le duché de Brabant au moyen âge. L'exemple de Dongelberg (1217)," in Wavre 1222-1972: 750me anniversaire des libertés communales (Wavre, 1973), pp. 57-93; "La région entre Dommel et Peel (Brabant septentrional). Peuplement rural, géographie politique et création de villes, 1200-1400 environ," Revue Belge de Philologie et d'Histoire, 60 (1982), pp. 791-808.

${ }^{76}$ K. Leenders, "Late dorpsvorming in het Brabantse zand," Historisch Geografisch Tijdschrift, 29 (2011), pp. 73-80; "Vier generaties dorpen in het Brabantse zand," Noordbrabants Historisch Jaarboek, 28 (2011), pp. 1-18; D. Vangheluwe and T. Spek, "De laatmiddeleeuwse transitie van landbouw en landschap in de Noord-Brabantse Kempen," Historisch Geografisch Tijdschrift, 26 (2008), pp. 123.

${ }^{77}$ M. De Keyzer, "The Impact of Different Distributions of Power on Access Rights to the Common Wastelands: The Campine, Brecklands and Geest Compared," Journal of Institutional Economics, 9 (2013), pp. 517-42. 
around late reclamation and colonization of previously uncultivated land. As summarized over 50 years ago by Bryce Lyon, "for well over a hundred years historians specializing in agrarian institutions of the Middle Ages have suggested that the vast land reclamation characterizing the eleventh and twelfth centuries in Western Europe contributed to the emancipation of the common man." 78 Thus, in many cases, colonists were lured to new inhospitable areas by the promise of favourable concessions and privileges from, for example, the Bishop of Utrecht and the Count of Holland, who had usurped complete regalian rights over vast expanses of wasteland after the collapse of the Carolingian Empire in the tenth century, ${ }^{79}$ and now needed labour to complete reclamation projects in the marshes of Holland. The peasant inhabitants of the settlements obtained freedom from serfdom and full and secure property rights. ${ }^{80}$ These settlements often took a linear or stretched form with houses lined up along dikes and waterways. Moreover, some colonists lived in favourable jurisdictions that allowed further reclamation of wasteland. ${ }^{81}$

Thus, in contrast to the incastellamento model which stresses the capacity of elites to use extra-economic coercion and force to move people into new concentrated settlements, this framework that emphasizes communalism instead highlights how the attraction of privileges and concessions motivated people to move into new settlements. In fact, many of the colonists in Holland's peat-lands originated from heavily manorialized societies and were looking to escape the constrictions of serfdom further inland (for example in the Central Dutch river area). ${ }^{82}$ Rural communities in these freer societies often had direct control over poor relief, judicial affairs, water management; they also collected taxes, organized military duties, and maintained internal order. Jurors could be elected as representatives of the community in local courts, and rural communities frequently developed their own by-laws. ${ }^{83}$ In addition, as public authorities, territorial lords often supported

${ }^{78}$ B. Lyon, "Medieval real estate developments and freedom," American Historical Review, 63 (1957) p. 47.

${ }^{79}$ P. van Cruyningen, "State, Property Rights and Sustainability of Drained Areas along the North Sea Coast, Sixteenth-Eighteenth Centuries," in B. van Bavel and E. Thoen (eds.), Rural Societies and Environments at Risk. Ecology, Property Rights and Social Organisation in Fragile Areas (Middle Ages-Twentieth Century) (Turnhout, 2013), p. 184.

${ }^{80} \mathrm{H}$. van der Linden, De cope: bijdrage tot de rechtsgeschiedenis van de openlegging der Hollands-Utrechtse laagvlakte (Assen, 1956), pp. 160-82; "Het platteland in het Noordwesten met de nadruk op de occupatie circa 1000-1300," Algemene Geschiedenis der Nederlanden, 2 (1982), pp. 48-82, esp. pp. 69-78; P. Henderikx, "Die mittelalterliche Kultivierung der Moore im Rhein-Maas-Delta (10.13. Jahrhundert)," Siedlungsforschung, 7 (1989), pp. 67-87; J. de Vries and A. van der Woude, The First Modern Economy: Success, Failure and Perseverance of the Dutch Economy, 1500-1815 (Cambridge, 1997), pp. 159-65.

${ }^{81}$ On the distinctive characteristics of these settlements; H. van der Linden, "De Oudhollandse veenstreek: zijn unieke — canonwaardige — plaats in de Nederlandse historie," Historisch Geografisch Tijdschrift, 27 (2009), pp. 97-108.

${ }^{82}$ Van Bavel, Manors and Markets, pp. 86-87.

${ }^{83}$ P. Hoppenbrouwers, "Op zoek naar de 'kerels'. De dorpsgemeente in de dagen van graaf Floris V," in D. de Boer, E. Cordfunke and H. Sarfatij (eds.), Wi Florens: De Hollandse graaf Floris V in de 
the position of colonists reclaiming land in direct antagonism to the powers of seigneurial lords. Further north of Holland, village communities in the Frisian and German coastal marshes such as Schleswig-Holstein had similar freedoms to reclaim land and settle into new concentrations, though here permission was often sought from territorial lords. ${ }^{84}$

Elsewhere in the twelfth and thirteenth centuries, settlers were enticed with the promise of reductions in manorial dues into new concentrated settlements carved out of the forest. ${ }^{85}$ In parts of Southern France in the eleventh and twelfth centuries, new areas of settlement known as "sauvetés" were established by monasteries and priories who offered protection and a place of refuge in exchange for bringing new land into cultivation, ${ }^{86}$ although lords also offered similar conditions in their so-called "castelnaux." 87 In a similar period in the Odenwald region of Southern Germany, the monastery of Lorsh stimulated the emergence of new linear forms of habitation by offering privileges to colonists. ${ }^{88}$ At Paderborn in the Westphalia of Northern Germany, skilled builders were coaxed into settling into new concentrated settlements with the promise of receiving excellent wages and secure property rights in exchange for carrying out Bishop Meinwerk"s building projects. ${ }^{89}$ Similar concessions and freedoms (although not nearly to the same extent) guided German colonization east of the Elbe, ${ }^{90}$ and tenants with harsh obligations as serfs in the Rhineland looked to escape by seeking these free tenures. ${ }^{91}$ For example, privileges from the Prince Bishop of Passau such as fewer taxes and dues on the movement and transfer of land, enticed settlers into difficult forested areas

samenleving van de dertiende eeuw (Utrecht, 1996), pp. 230-31; W. Ehbrecht, "Gemeinschaft, Land und Bund im Friesland des 12. bis 14. Jahrhunderts," in H. van Lengen (ed.), Die Friesische Freiheit des Mittelalters: Leben und Legende (Aurich, 2003), pp. 154-60.

${ }^{84}$ M. Allemeyer, Kein Land ohne Deich. Lebenswelten einer Küstengesellschaft in der Frühen Neuzeit (Göttingen, 2006), p. 139.

${ }^{85}$ E. Berger and H-F. Delaborde (eds.), Recueil des actes de Philippe Auguste (Paris, 1916), I, no. 51 .

${ }^{86}$ C. Higounet, "Hospitaliers et Templiers: peuplement et exploitation rurale dans le sud-ouest de la France au Moyen Âge," Cahiers de Flaran, 6 (1984), pp. 61-78.

${ }^{87}$ P. Simon, "Les castra du Néracais et du Condomnois d'après les hommages de 1286," Revue de l'Agenais (1984), pp. 25-34.

${ }^{88}$ H-J. Nitz, Die ländliche Siedlungsformen des Odenwaldes: Untersuchungen über ihre Typologie und Genese die Prinzipien der räumlichen Organisation des mittelalterlichen Siedlungsbildes (Heidelberg, 1962), pp. 83-112; "The Church as Colonist: The Benedictine Abbey of Lorsch and Planned Waldhufen Colonization in the Oldenwald," Journal of Historical Geography, 9 (1983), pp. $105-$ 23.

${ }^{89}$ F. Irsigler, "Divites und Pauperes in der Vita Meinwerci. Untersuchungen zur wirtschaftlichen und sozialen Differenzierung der Bevölkerung Westfalens im Hochmittelalter," Vierteljahrschrift für Sozial- und Wirtschaftsgeschichte, 57 (1970), pp. 449-99.

${ }^{90}$ For the best general view see R. Bartlett, The Making of Europe: Conquest, Colonisation and Cultural Change, 950-1350 (London, 1993).

${ }^{91}$ G. Richter, "Kulturlandschaft und Wirtschaft," in H. Heckmann (ed.), Mecklenburg-Vorpommern. historische Landeskunde Mitteldeutschlands (Würzburg, 1989), p. 129; W. Ribbe, "Die Anfänge von Berlin/Cölln als Forschungproblem," Jahrbuch für die Geschichte Mittel- und Ostdeutschlands, 34 (1985), p. 7. 
in Bavaria in the 1300s, stimulating very distinctive linear settlements known as Waldhufendorfen. ${ }^{92}$

One of the fundamental characteristics of this kind of explanatory framework is the prominence given to "late" land reclamation and colonization. Thus, it is clear from the outset that the "communalism" as a concept can only really be applicable to a certain number of settlements that developed from the twelfth or thirteenth centuries onwards. However, even when talking explicitly about new concentrated settlements created from high- or late-medieval reclamation activity, one still has to wonder whether the framework can be applicable across Western Europe. In fact, in some areas, some scholars have linked the desire for freedom and autonomy from manorial or seigneurial jurisdictions not to the concentration of settlement, but to the emergence of new forms of dispersed or isolated settlement. Work on the woodland assarts of the high Middle Ages is a case in point. ${ }^{93}$ Aside from that basic point, however, it bears mention that, although the increasing colonization of new territories and upward population trends characterized the period of the eleventh to thirteenth centuries, the new rural settlements that resulted cannot always be explained through reference to a quest for freedom or autonomy. Indeed, even during the late Middle Ages, lords could invest heavily in marshland colonization activity. ${ }^{94}$

In fact in some areas such as the Po Valley in Northern Italy, newly constructed villages from the high Middle Ages onwards fitted very nicely into the larger story of the subordination of the countryside to the political and economic aims of cities..$^{95}$ Peasant reclamation initiatives did not bring widespread freedoms or the "emancipation of the common man" as suggested in Bryce Lyon's influential article. Although seigneurial lordships and manorialism withered away very early in North and Central Italy, the old elements of rural repression were replaced by new forms of urban domination..$^{96}$ In Northern and Central Italy, the urban population doubled between 1000 and 1300 - a higher rate than elsewhere in Western

${ }^{92}$ L. Veit, Passau: Das Hochstift.historischer Atlas von Bayern (Munich, 1978), pp. 287-8, 4423; H-J. Nitz, "Planmäßige Siedlungsformen zwischen dem österreichischen Waldviertal und dem passauer Abteiland," Ostbairische Grenzmarken, 27 (1985), p. 61.

${ }^{93}$ B. Roberts, "The Historical Geography of Moated Homesteads: The Forest of Arden, Warwickshire," Transactions of the Birmingham and Warwickshire Archaeological Society, 88 (1976-77), pp. 61-70; A. Chedeville, "Un défrichement en Bretagne à la fin du XIe siècle: histoire économique et géographie féodale," in J-M. Duvosquel and E. Thoen (eds.), Peasants and Townsmen in Medieval Europe. Studia in honorem Adriaan Verhulst (Ghent, 1995), pp. 397-428; R. Latouche, "Défrichement et peuplement rural dans La Maine du IXe au XIIIe siècle," Le Moyen Age, 3 (1948), pp. 77-87; R. Hilton, "Social Structure of Rural Warwickshire in the Middle Ages," in The English Peasantry in the Later Middle Ages (Oxford, 1975), pp. 113-8; I. Øye, "Settlement Patterns and Field Systems in Medieval Norway," Landscape History, 30 (2009), p. 43.

${ }^{94}$ J. Galloway, "Storm Flooding, Coastal Defence and Land Use around the Thames Estuary and Tidal River c. 1250-1450," Journal of Medieval History, 35 (2009), pp. 171-88.

${ }^{95}$ M. Campopiano, "Land Clearance and Water Management in the Po Valley in the Central and Late Middle Ages (Ninth-Fifteenth Centuries): The Role of Rural Communities," Journal of Medieval History (forthcoming 2013).

${ }^{96}$ D. Waley, The Italian City-Republics (New York, 1988), pp. 84-85. 
Europe (except Holland and Flanders). ${ }^{97}$ As these urban agglomerations increased in size, number and stature, the number of "non-productive" or dependent citizens also grew. ${ }^{98}$ Cities realized they had, on the one hand, to create direct explicit legal relationships with their hinterlands, ${ }^{99}$ and, on the other hand, to exploit these hinterlands more intensively. In that sense, urban institutions, governments and burghers became the new "feudal lords" of the late Middle Ages and early modern period in Europe. ${ }^{100}$ This was not a sharp discontinuity with previous forms of social and political organization. The distinction between "urban" and "rural" elite interest groups was not always clear-cut; frequently rural signori with land and castles in the contadi were at the same time urban citizens or burghers. In that way rural lordships were easily integrated into new cadres of control established by cities. ${ }^{101}$ Cities extended their control over an expanding contado by reclaiming more land, but supported these colonization activities through jurisdictions that subsumed rural communities into their governmental structure. ${ }^{102}$ Land reclamation became an effective way to legitimize of urban control and socio-political influence over the countryside in the Po Valley. ${ }^{103}$

Just as seigneurial lords had done before them, urban governments tried, in the interests of water management, to extract labour from rural communities. In the second half of the eleventh century, Pavia asked nearby inhabitants of the villages to work the locks of the Ticino River. ${ }^{104}$ As a result of Verona's food-supply problems in the twelfth and thirteenth centuries, the commune reclaimed new land by settling colonists within "free boroughs" such as Villafranca in 1184 or at Palù, where newcomers were each given a standardized plot on which to work and build a house. ${ }^{105}$ Elsewhere, at the swamps of the commune of Verona, wasteland was

${ }^{97}$ P. Malanima, "Urbanisation and the Italian Economy during the Last Millennium," European Review of Economic History, 9 (2005), pp. 99-102.

${ }^{98} \mathrm{~S}$. Ciriacono, "L'economia regionale veneta in epoca moderna. Note a margine del caso bergamasco," in Venezia e la Terraferma. Economia e società (Bergamo, 1989), p. 45; G. Del Torre, Venezia e la Terraferma dopo la guerra di Cambrai. Fiscalità e amministrazione (1515-1530) (Milan, 1986), pp. 199-216.

${ }_{99}$ M. Vaini, Dal comune alla signoria. Mantova dal 1200 al 1328 (Mantua, 1986), pp. 137-64, 316-22; C. Mozzarelli, Mantova e i Gonzaga dal 1382 al 1707 (Turin, 1987), pp. 53-80.

${ }^{100}$ S. Epstein, "Cities, Regions and the Late Medieval Crisis: Sicily and Tuscany Compared," Past and Present, 130 (1991), pp. 3-50; "Town and Country: Economy and Institutions in Late Medieval Italy," Economic History Review, 46 (1993), pp. 453-77.

${ }^{101}$ Epstein, "Town and Country"; G. Tabacco, Egemonie sociali e strutture del potere nel medioevo italiano (Turin, 2000), pp. 142-67; P. Jones, The Italian City-State: From Commune to Signoria, (Oxford, 2004), pp. 288-332.

${ }^{102}$ M. Campopiano, "Rural Communities, Land Clearance and Water Management in the Po Valley in the Central and Late Middle Ages," Journal of Medieval History 39 (2013), pp. 377-93.

${ }^{103}$ D. Curtis and M. Campopiano, "Medieval Land Reclamation and the Creation of New Societies. Comparing Holland and the Po Valley, c.800-c.1500," Journal of Historical Geography (forthcoming 2013).

${ }^{104}$ P. Grillo, "Comuni urbani e poteri locali nel governo del territorio in Lombardia (XII-inizi XIV secolo)," in L. Chiappa Mauri (ed.), Contado e città in dialogo. Comuni urbani e comunità rurali nella Lombardia medievale (Milan, 2003), pp. 45-46.

${ }^{105}$ A. Castagnetti, "Primi aspetti di politica annonaria nell'Italia comunale. La bonifica della 'palus comunis Verone' (1194-1199)," Studi Medievali, 13 (1974), pp. 363-481. 
bought by a professional and commercial consortium of Veronese citizens, as well as by a group of aristocrats and office-holders. ${ }^{106}$ Urban investment stimulated similar reclamation and formation of new settlements in the contado around Cremona, while cities such as Milan invested in the construction of canals to expand field irrigation. ${ }^{107}$

As early statutes attest, rural communities essentially became compelled in the thirteenth and fourteenth centuries to colonize unclaimed land. ${ }^{108}$ For example, the statutes of Reggio Emilia ordered the assarting of trees near the village of Rivalta. ${ }^{109}$ Cities also struck up agreements with large rural landowners: a case in point is the pact between Bologna and a consortium of lords which aimed to entice villages into working on a canal that would bring water from the Reno River to the city. ${ }^{110}$ The statutes of Parma in the 1200s compelled the rural communities which benefited from the canal connecting Sant'Ilario, Taneto, and Prato Ottesola - to maintain the structure. ${ }^{111}$ The statutes of Ferrara around the same time show that officials of the city had to discuss with inhabitants of local villages any matters regarding the improvement of water management, and furthermore, that rural communities had to provide a labour force to work the river embankments. ${ }^{112}$ In Reggio Emilia consuls from the rural communities had to appear in front of courts every month to report malfunctions in the infrastructure. ${ }^{113}$ Some village statutes were actually integrated into the Public Water Statutes of Milan in the 1300s. ${ }^{114}$ Thus in sum, the late-reclaimed settlements that developed may have had "charters of freedom" in the sense they were free from repressive rural lordships, but they were still subordinate to the financial and political power of the urban administrative apparatus. ${ }^{115}$ The line between "freedom" and "coercion" in connection with settlement development has become rather blurred through recent research.

${ }^{106} \mathrm{Ibid}, 399-410$.

${ }^{107}$ G. Chittolini, "I beni terrieri del Capitolo della cattedrale di Cremona fra il XIII e il XIV secolo," Nuova Rivista Storica, 49 (1965), pp. 218-24; P. Boucheron, Water and Power in Milan, c. 12001500," Urban History, 28 (2001), pp. 180-93.

${ }^{108}$ V. Fumagalli, "Il paesaggio si trasforma. Colonizzazione e bonifica durante il Medioevo. L'esempio emiliano," in B. Andreolli, V. Fumagalli and M. Montanari (eds.), Le campagne italiane prima e dopo il Mille. Una società in trasformazione (Bologna, 1985), pp. 104-5; G. Fantoni, L'acqua a Milano. Uso e gestione nel basso medioevo (1385-1535) (Bologna, 1990), p. 39.

${ }^{109}$ A. Campanini (ed.), I rubricari degli statuti comunali di Reggio Emilia (secc. XIII-XVI) (Reggio Emilia, 1997), pp. 31-58; A. Cerlini (ed.), Consuetudini e statuti reggiani del sec. XIII (Milan, 1933), p. 23.

${ }^{110}$ D. Balestracci, "La politica delle acque urbane nell'Italia comunale," Mélanges de l'Ecole Française de Rome. Moyen Age, 104 (1992), p. 442.

${ }^{111}$ Monumenta Historica ad provincias parmensem et Placentia pertinentia (Parma, 1860), p. 382.

${ }^{112}$ R. Zupko and R. Laures, Straws in the Wind. Medieval Urban Environmental Law. The Case of Northern Italy (Boulder, 1996), p. 69.

${ }^{113}$ A. Campanini (ed.), "Quam partem dugalium tenentur facere mezadri et laboratores," in I rubricari degli statuti comunali di Reggio Emilia (secc. XIII-XVI) (Reggio Emilia, 1997), p. 193, 232.

${ }^{114}$ G. Porro Lambertenghi (ed.), "Statuti delle strade e delle acque del contado di Milano fatti nel 1346," Miscellanea di Storia Italiana, 7 (1869), pp. 415-20.

${ }^{115}$ F. Menant, "Les chartes de franchises de l'Italie communale," in M. Bourin and P. Martin (eds.), Pour anthropologie du prélèvement seigneurial dans les campagnes médiévales (XIe-XIVe). Réalités et représentations paysannes (Paris, 2004), pp. 239-69. 


\section{Field Systems and Resource Management}

One of the classic approaches to the history of settlement in medieval Western Europe stresses the role that field organization played in the process. ${ }^{116}$ In particular, scholars have frequently associated the movement of rural people into concentrated settlements with the establishment of open-field systems, which distributed basic agricultural holdings in unenclosed parcels. ${ }^{117}$ However, unlike the two explanatory frameworks described above, some of the key attributes of this paradigm remain unclear. With regard to the "agents of settlement change," there is still much debate and lack of clarity about who was responsible for laying out the open fields. Did manorial lords instigate the system? Was it a logical response of common rural people to their economic situation? Or was it a joint effort? The origins of the open field system are difficult to ascertain, partly because the intention to rearrange the fields in this way is not revealed in many documentary sources. Complicating matters is the fact that the chronology, speed, and intensity of open-field formation appears to be highly divergent across regions, thus making it even more difficult to establish causality. We know that settlement concentration and the establishment of open fields are linked in many places, but we are uncertain about which came first and about whether the two processes have separate or common origins. ${ }^{118}$

That open fields and concentrated settlements complement each other has at least been established on an abstract level. The theoretical benefits of living in concentrations at the heart of scattered plots in open fields have frequently been seen as promoting "logical" decisions based on economic and ecological reasoning. Essentially, the open-field system helped medieval rural societies withstand the possibility of "Malthusian crises" caused by increasing population pressure on finite amounts of land. Indeed, its proliferation may even have gone hand-in-hand with exceptional population growth between the tenth and thirteenth centuries, ${ }^{119}$ although it did emerge in some areas earlier than the ninth century. ${ }^{120}$ Some open fields started small and then expanded through assarting. ${ }^{121}$ According to the theory, as population levels increased, the need for rural inhabitants to divide their resources more equitably became more acute. The open fields allowed for a more egalitarian division of land as every household's holdings were divided into small

${ }^{116}$ G. Astill, "The Long and the Short: Rural Settlement in Medieval England," in R. Goddard, M. Muller and J. Langdon (eds.), Survival and Discord in Medieval Society: Essays in Honour of Christopher Dyer (Turnhout, 2010), p. 12.

${ }^{117}$ Basic definition provided in C. Taylor, "Archaeology and the Origins of Open-Field Agriculture," in T. Rowley (ed.), The Origins of Open Field Agriculture (London, 1981), p. 13.

${ }^{118}$ S. Oosthuizen, "Medieval Field Systems and Settlement Nucleation: Common or Separate Origins?," in N. Higham (ed.), The Landscapes of Anglo-Saxon England (Woodbridge, 2010), p. 131.

${ }^{119}$ A sceptical view on the link between open-field proliferation and demographic pressure is found in C. Lewis, P. Mitchell-Fox and C. Dyer, Village, Hamlet and Field: Changing Medieval Settlements in Central England (London, 1997), pp. 213-16.

${ }^{120}$ S. Oosthuizen, "New Light on the Origins of Open-Field Farming?" Medieval Archaeology, 49 (2005), pp. 165-93.

${ }^{121}$ C. Higounet, Défrichements et Villeneuves du Bassin Parisien (XIe-XIVe siècles) (Paris, 1990). 
morsels scattered across the fields, while the community often lived in a concentrated settlement at the heart of these fields. ${ }^{122}$ Not only did scattering make transport and labour costs more equal, but it was also an exercise in risk-management as no single person could monopolize the best soils; if one field harvest failed, this was not disastrous. ${ }^{123}$ The same risk-limitation concerns still informs the persistence of fragmented land distributions in parts of Asia and Africa today. ${ }^{124}$

The open field system could also lead to sustainable ecological management. A variation of the open field system, the system of "common fields" 25 allowed one of the fields (usually one out of three) ${ }^{126}$ to remain fallow on a rotating basis, thereby not exhausting the nutrients of the soil. ${ }^{127}$ Furthermore, this system pushed people towards collective regulation of the harvest, which in turn prevented grain theft and ensured orderly grazing on the stubble. ${ }^{128}$ It also fostered collective action: local people often banded together into small groups to manage plough-teams, while oxen - which were expensive - were sometimes collectively acquired. ${ }^{129}$ In the common-field system too, each participant had a number of obligations and restrictions to respect: animals, for example, could only graze on the fields at certain times of the year. The community members themselves often enforced such regulations, although in some places, more formal councils were involved. ${ }^{130} \mathrm{In}$

${ }^{122}$ R. Hoffman, "Medieval Origins of the Common Fields," in W. Parker and E. Jones (eds.), European Peasants and their Markets (Princeton, 1975), pp. 23-71. Holdings could be divided with strict equality; for example see R. Hilton, The Economic Development of some Leicestershire Estates in the Fourteenth and Fifteenth Centuries (Oxford, 1947), pp. 153-55; D. Roden, "Field Systems of the Chiltern Hills and their Environs," in A. Baker and R. Butlin (eds.), Studies of Field Systems in the British Isles (Cambridge, 1973), p. 349.

${ }^{123}$ C. Dahlman, The Open Field System and Beyond (Cambridge, 1980), pp. 111-14; H. Fox, "Some Ecological Dimensions of Medieval Field systems," in K. Biddick (ed.), Archaeological Approaches to Medieval Europe (Kalamazoo, 1984), pp. 119-58.

${ }^{124}$ A. Heston and D. Kumar, "The Persistence of Land Fragmentation in Peasant Agriculture: An Analysis of South Asian Cases," Explorations in Economic History, 20 (1983), pp. 199-220; S. Simmons, "Land Fragmentation in Developing Countries: The Optimal Choice and Policy Implications," Explorations in Economic History, 25 (1988), pp. 254-62; N. Sengupta, "Fragmented Landholding, Productivity, and Resilience Management," Environment and Development Economics, 11 (2006), pp. 507-32; T. Nguyen, E. Cheng and C. Findlay, "Land Fragmentation and Farm Productivity in China in the 1990's," China Economic Review, 7 (1996), pp. 169-80.

${ }^{125}$ On the definition of the "common fields" see J. Thirsk, "The Common Fields," Past and Present, 29 (1964), p. 3.

${ }^{126}$ On this variation across Western Europe; H. Hildebrandt, "Systems of Agriculture in Central Europe up to the Tenth and Eleventh Centuries," in D. Hooke (ed.), Anglo-Saxon Settlements (Oxford, 1998), pp. 287-88.

${ }^{127}$ J. Pretty, "Sustainable Agriculture in the Middle Ages on the English Manor," Agricultural History Review, 38 (1990), pp. 1-19; B. Campbell, "Ecology versus Economics in late Thirteenth and Early Fourteenth Century English Agriculture," in D. Sweeney (ed.), Agriculture in the Middle Ages: Technology, Practice, and Representation (Philadelphia, 1995), pp. 76-108.

${ }^{128}$ W. Ault, Open-Field Farming in Medieval England. A Study of Village By-Laws (London, 1972), pp. 27-40.

${ }_{129}$ W. Rösener, Bauern im Mittelalter (Munich, 1985), p. 151.

${ }^{130}$ D. Curtis, "Tine De Moor's 'Silent Revolution'. Reconsidering her Theoretical Framework for Explaining the Emergence of Institutions for Collective Management of Resources," International 
short, the idea is that the open fields and concentrated settlements complemented each other in a "rational" system based on the limitation and equitable social distribution of risk. ${ }^{131}$

The association of the open field system with the development of concentrated settlements is supported to some extent by their simple geographical coincidence. A number of insightful maps have been able to plot the general locations where open fields (in a variety of forms) developed, and many (though not all) match up with characteristic concentrated settlement landscapes - even if this is rather crude. ${ }^{132}$ One of the classic associations could be seen in the Midland Belt of Central England: mapping based on the overlaying of nineteenth-century cadastral surveys has shown the clear combination of open fields and large villages. ${ }^{133}$ Interestingly, this form of agricultural organization was introduced to some of the earliest English colonies in Massachusetts, even if the experiment proved to be short-lived. ${ }^{134}$ The system of fragmented unenclosed parcels was also a feature across large parts of Southern Italy and generally matched up with the regions characterized by large concentrated settlements known as "agro-towns" (essentially towns with agricultural functions), although this concentrated town structure did not necessarily proliferate in the Middle Ages. ${ }^{135}$ The correlation between open fields and concentrated settlements is often also driven home by comparing concentrated settlements with dispersed or isolated settlement structures. In the southern part of the province of Limburg in the Low Countries, tenant farmers lived on isolated farms on consolidated blocks while nearby peasants with fragmented smallholdings lived in villages and hamlets. ${ }^{136}$

As mentioned in the introductory paragraph to this section, however, there are a number of problems, limitations, and inconsistencies involved in merely linking

Journal of the Commons, 7 (2013), p. 213. Examples of more formal councils include the Dorfgenossenschaft in Germany and the bystämman in Sweden. On these, see respectively W. Rösener, Peasants in the Middle Ages (Chicago, 1992), p. 46 and V. Moberg, A History of the Swedish People (New York, 1973), I, p. 40.

${ }^{131}$ D. McCloskey, "English Open Fields as Behaviour toward Risk," Research in Economic History, 1 (1976), pp. 124-70; "The Prudent Peasant: New Findings on Open Fields," Journal of Economic History, 51 (1991), pp. 343-55; M. Bailey, "Beyond the Midland Field System: The Determinants of Common Rghts over the Arable in Medieval England," Agricultural History Review, 58 (2010), p. 160.

${ }^{132}$ H. Clout, "The European Countryside: Contested Space," in B. Graham (ed.), Modern Europe: Place, Culture and Identity (London, 1998), pp. 287-309; R. Lebeau, Les grands types de structures agraires dans le monde (Paris, 1969), p. 50; J. Meeus, "Pan-European Landscapes," Landscape and Urban Planning, 31 (1995), pp. 57-79.

${ }^{133}$ Wrathmell and Roberts, Region and Place, pp. 1-10.

${ }^{134}$ P. Greven Jr., "Old Patterns in the New World: The Distribution of Land in Seventeenth-Century Andover," in D. Ward (ed.), Geographic Perspectives on America's Past: Readings on the Historical Geography of the United States (New York, 1979), pp. 121-28.

${ }^{135}$ Compare the maps of open fields and agro-towns in P. Birot and P. Gabert, La Méditerranée et le Moyen-Orient (Paris, 1964), pp. 148-49; D. Curtis, "Is There an Agro-Town Model for Southern Italy? Exploring the Diverse Roots and Development of the Agro-Town Structure through a Comparative Case Study in Apulia," Continuity and Change, 28 (2013), p. 1.

${ }^{136}$ J. Renes, "Krijt/lösslandschap," in S. Barends et al. (eds.), Het Nederlandse landschap: een historisch-geografisch benadering (Utrecht, 2000), pp. 128-41. 
the two processes of open-field formation and concentrated settlement together. No kind of causality has been reached yet - at least not convincingly for large areas. Did the establishment of the open fields really lead to the concentration of settlement, or can this be turned on its head? Perhaps the establishment of concentrated settlements in Western Europe in turn necessitated a change in the organization of the fields. Certainly some literature does point to the rapid restructuring of settlement after the establishment of the open fields in some regions. In areas of Central England, for example, it has been argued that from the eleventh century Norman lords planned new orthodox forms of open fields, and that these tenurial changes consequently led to a rapid transformation of settlement structures. ${ }^{137}$ Often this kind of intense change in the field system and settlement structure is indicative of an element of planning from above. ${ }^{138}$ The entire restructuring of settlement into concentrations as a direct result of the establishment of new open fields has been a dominant feature of important work on the medieval English landscape. ${ }^{139}$

Yet, does this kind of theory mean that the pre-existing habitations before the establishment of the open fields were dispersed or scattered across the landscape? Certainly this has been argued for some places, ${ }^{140}$ but the point is that more and more scholars are becoming aware that settlement concentration may have occurred in the early-medieval period before the establishment of open fields - even if we still accept that the open fields often brought about further changes to the settlement structure. Some scholars have actually shown settlement concentration to be a long-term process that encompasses a number of different phases or smaller shifts. Concentrated settlements in areas of open fields often had an element of concentration before the fields were even adopted, sometimes taking the form of early informal clustering around points of pasture or meadow. ${ }^{141}$ Probably we

${ }^{137}$ R. Faith, The English Peasantry and the Growth of Lordship (London, 1997), pp. 224-44; S. Oosthuizen, "Medieval Settlement Relocation in West Cambridgeshire: Three Case Studies," Landscape History, 19 (1997), pp. 43-55.

${ }^{138}$ H. Wunder, "Peasant Organization and Class Conflict in Eastern and Western Germany," in T. Aston and C. Philpin (eds.), The Brenner Debate: Agrarian Class Structure and Economic Development in Pre-Industrial Europe (Cambridge, 1985), p. 94.

${ }^{139}$ D. Hall, "The Origins of Open Field Agriculture — The Archaeological Fieldwork Evidence," in T. Rowley (ed.), The Origins of Open Field Agriculture (London, 1981), pp. 35-36; Lewis, MitchellFox and Dyer, Village, Hamlet and Field, pp. 202-3; D. Hooke, The Landscape of Anglo-Saxon England (Leicester, 1998), p. 115.

${ }^{140}$ For example; R. Schreg, "Die Archäologie des mittelalterlichen Dorfes in Süddeutschland; Probleme - Paradigmen — Desiderate," Siedlungsforschung, 24 (2006), pp. 141-62; E. Thoen, "Een model voor integratie van historische geografie en ekonomische strukturen in Binnen-Vlaanderen: de historische evolutie van het landschap in de Leiestreek tussen Kortrijk en Gent tijdens de Middeleeuwen," Jaarboek Heemkring Scheldeveld, 19 (1990), pp. 4-34.

${ }^{141}$ A. Brown and G. Foard, "The Saxon Landscape: A Regional Perspective," in The Archaeology of Landscape: Studies Presented to Christopher Taylor (Manchester, 1998), p. 74; C. Taylor, "Nucleated Settlement: A View from the Frontier," Landscape History, 24 (2002), pp. 53-71; G. Foard, "Systematic Fieldwalking and the Investigation of a Saxon Settlement in Northamptonshire," World Archaeology, 9 (1978), p. 370; S. Oosthuizen, Landscapes Decoded: The Origins and Development of Cambridgeshire's Medieval Fields (Hatfield, 2006), pp. 146-47. 
should not be too surprised at this, given that some recent research is also showing that open fields were frequently laid out by incorporating older (perhaps prehistoric) landscape arrangements. ${ }^{142}$ The "interrupted" or "incremental" view of medieval settlement concentration has also been used by Frans Theeuws for the early-medieval region of the pagus Texandrië (roughly coterminous with the sandy area of Belgian and Dutch Brabant). ${ }^{143}$

Still further problems emerge. Even if we do accept the general premise that open fields and concentrated settlements were linked during various stages of the Middle Ages, there is still no consensus as to why open fields were adopted in some parts of Western Europe, but not in others. We know, of course, the "theoretical benefits" of the social distribution of risk, but we do not know why some societies apparently did not care about risks (highly unlikely) or chose alternative methods for limiting their exposure to crises. Stephen Rippon ${ }^{144}$ has recently listed as many as seven different explanatory variables for understanding the proliferation of open fields including ethnicity, estate fragmentation, the balance of arable and pasture, cultural emulation, products of antecedent landscapes, lordship, and soil types $^{145}$ - and probably to those we could add factors such as population pressure, ${ }^{146}$ the emergence of integrated grain markets, ${ }^{147}$ and fragmentation of landownership. ${ }^{148}$ Some of these factors, such as ethnicity, have furthermore been readily dismissed; others, such as "soil type" are problematic given that the same soil type is sometimes found in areas with divergent settlement developments. ${ }^{149}$ The simple equation of open fields and concentrated settlements becomes even more complicated when we take into account the existence of small pockets of dispersed or scattered settlement in areas which had open fields, ${ }^{150}$ or those areas

${ }^{142}$ T. Spek, "Entstehung und Entwicklung historischer Ackerkomplexe und Plaggenböden in den Eschlandschaften der nordöstlichen Niederlande (Provinz Drenthe)," Siedlungsforschung, 24 (2006), p. 226.

${ }^{143}$ F. Theeuws, "Settlement Research and the Process of Manorialisation in Northern Austrasia," in S. Gasparri (ed.), 774, ipotesi su una transizione (Turnhout, 2008), p. 211.

${ }^{144}$ S. Rippon, Beyond the Medieval Village: The Diversification of Landscape Character in Southern Britain (Oxford, 2008).

${ }^{145}$ A framework used in T. Williamson, Shaping Medieval Landscapes: Settlement, Society, Environment (Macclesfield, 2003), pp. 180-99.

${ }^{146}$ B. Campbell, "Population Growth and the Genesis of Commonfields on a Norfolk Manor," Economic History Review, 33 (1980), pp. 174-92.

${ }^{147}$ Used in particular for early-modern open-field formation in parts of Eastern Europe; G. Demidowicz, "Planned Landscapes in North-East Poland, the Sura Estate, 1500-1760," Journal of Historical Geography, 11 (1985), pp. 21-47; R. French, "The Three-Field System of $16^{\text {th }}$-century Lithuania," Agricultural History Review, 18 (1970), pp. 106-25.

${ }^{148}$ A. Krenzlin, "Zur Genese der Gewannflur in Deutschland, nach Untersuchungen im nördlichen Unterfranken," Geografiska Annaler, 43 (1961), pp. 109-202.

${ }^{149}$ C. Dyer, "Dispersed Settlements in Medieval England. A Case Study of Pendock, Worcestershire," Medieval Archaeology, 34 (1992), p. 118.

${ }^{150}$ E. Glässer, Südnorwegische Agrarlandschaften: Struktur und neuzeitliche Entwicklungsprobleme ländlicher Siedlungs- und Wirtschaftsformen, gezeigt an Aktiv- und Passivräumen Rogalands und Agders (Wiesbaden, 1975), p. 46; S. Harrison, "Open Fields and Earlier Landscapes: Six Parishes in South-East Cambridgeshire," Landscapes, 3 (2002), pp. 35-54; C. Taylor, Village and Farmstead (London, 1983), p. 131. 
which had open fields integrated within other types of field organization such as private enclosures ${ }^{151}$ or the infield-outfield system. ${ }^{152}$ Small hamlets and dispersed farmsteads, moreover, existed simultaneously and were often interspersed with concentrated settlements, ${ }^{153}$ in the same way that concentrated settlements could be found dotted among dominant patterns of dispersed settlement. ${ }^{154}$ One final limitation of this explanatory framework is that most of its proponents do not work outside their "national" research traditions or engage in systematic comparative analysis. ${ }^{155}$ The British tradition of research into the open fields is arguably the most well-developed, but one problem (as with much British rural history) is that it runs separate and is not embedded within research on open fields in the European mainland. ${ }^{156}$

\section{Urbanization and Market Integration}

Scholars have also accounted for settlement concentration through reference to the increasing commercialization of the medieval economy. In considering "agents of settlement change," research in this category has looked more deeply at "absentee" social groups - for example, at the role of "outside" urban forces in stimulating new forms of settlement concentration in the countryside. Second, in terms of chronology, this framework often gives more precedence to the high Middle Ages, when parts of Western Europe started to become more urbanized and stronger political and economic links began to emerge between town and countryside. Third, with regard to the dynamism and speed of the settlement concentration process, this framework tend to highlight rapid and intense changes in settlement structure; such as the process through which new settlements were founded quickly in response to favourable grants to establish market centres.

${ }^{151}$ G. Astill and W. Davies, A Breton Landscape (London, 1997), p. 13; P. Herring, "Cornish Strip Fields," in S. Turner (ed.), Medieval Devon and Cornwall: Shaping an Ancient Countryside (Macclesfield, 2006), pp. 44-77.

${ }^{152}$ R. Dodgshon, "West Highland and Hebridean Landscapes: Have they a History without Runrig?," Journal of Historical Geography, 19 (1993), pp. 383-98.

${ }^{153}$ C. Taylor, "Dispersed Settlement in Nucleated Areas," Landscape History, 17 (1995), pp. 27 34; R. Jones and C. Lewis, "The Midlands: Medieval Settlements and Landscapes," in Christie and Stamper (eds.), Medieval Rural Settlement, pp. 190-91.

${ }^{154}$ E. Martin, "Norfolk, Suffolk, and Essex: Medieval Rural Settlement in 'Greater East Anglia'," in Christie and Stamper (eds.), Medieval Rural Settlement, pp. 234-35; S. Wrathmell, "Northern England: Exploring the Character of Medieval Rural Settlements," in Idem, p. 253.

${ }^{155}$ One fine exception can be found at J. Renes, "Grainlands. The Landscape of Open Fields in a European Perspective," Landscape History, 31 (2010), pp. 37-70. On this problem in rural history, in general, see D. Curtis, "Trends in Rural Social and Economic History of the Pre-Industrial Low Countries: Recent Themes and Ideas in Journals and Books of the Past Five Years (2007-2013)," BMGN: Low Countries Historical Review, 128 (2013), p. 61.

${ }^{156}$ Noted in J. Renes, "De veengebieden rond de Noordzee; landschapsgeschiedenis en landschapsonderzoek," in J. Beenakker, F. Horsten, A. de Kraker and J. Renes (eds.), Landschap in ruimte en tijd: liber amicorum aangeboden aan prof. $d r$. Guus J. Borger bij gelegenheid van zijn 65ste verjaardag en zijn afscheid als hoogleraar in de historische geografie aan de Universiteit van Amsterdam en de Vrije Universiteit (Amsterdam, 2007), pp. 287-300. 
In an extensive literature, scholars have suggested that some rural regions enjoyed the fruits of increasing integration with urban markets, with the growth of towns and their markets promoting the development of commercialized agriculture as well as the development of new forms of non-agricultural production in rural areas. ${ }^{157}$ Even in poorly urbanized areas such as Apulia in southern Italy during the twelfth and thirteenth centuries, the establishment of small centres such as Troia and Foggia was enough to stimulate economic activity in the countryside and foster the emergence of new small settlements with concentrated points of production. ${ }^{158}$ Many new late-medieval settlements appeared as a result of shifting trading patterns. In Sicily, for example, some settlements were tied to the formation of permanent markets, while others were more transient and temporary and linked to rural fairs. ${ }^{159}$ The transitory nature of some of these new settlements was especially visible in parts of southern France, where many rural centres went into a cycle of decline and re-emergence. ${ }^{160}$ Some coastal settlements emerged in relation to specialized non-agricultural activities such as fishing, ${ }^{161}$ while in some mountain areas, the high- and late-medieval concentration of settlement resulted from increased urban demand for mountain produce such as meat, wool, and wood. ${ }^{162}$ In peat-rich and marsh areas, river-borne trade was encouraged by the construction of lodes linking small rural market centres to navigable waterways. ${ }^{163}$

${ }^{157}$ G. Grantham, "Espaces privilégiés: productivité agricole et zones d'approvisionnement dans l'Europe pré-industrielle,” Annales: Histoire, Sciences Sociales, 52 (1997), pp. 697-725; J. Masschaele, Peasants, Merchants and Markets: Inland Trade in Medieval England, 1150-1350 (New York, 1997); P. Clark, European Cities and Towns: 400-2000 (Oxford, 2009), pp. 44-5. See also, B. Campbell et al., A Medieval Capital and its Grain Supply: Agrarian Production and Distribution in the London Region, c. 1300 (London, 1993); D. Keene, "Medieval London and its Region," London Journal, 14 (1989), pp. 103-4; J. Galloway, "London's Grain Supply: Changes in Production, Distribution and Consumption During the Fourteenth Century," Franco-British Studies, 20 (1995), pp. 23-34; J. Lee, "Feeding the Colleges: Cambridge's Food and Fuel Supplies, 1450-1560," Economic History Review, 56 (2003), pp. 243-62; M. Kowaleski, Local Markets and Regional Trade in Medieval Exeter (Cambridge, 1995), pp. 293-300; W. Held, Zwischen Marktplatz und Anger: Stadt-Land-Beziehungen im 16. Jahrhundert in Thüringen (Weimar, 1988), pp. 108-10; L. Vardi, The Land and the Loom: Peasants and Profit in Northern France, 1680-1800 (Durham, 1993).

${ }^{158}$ P. Oldfield, "Rural Settlement and Economic Development in Southern Italy: Troia and its Contado, c. 1020 - c. 1230," Journal of Medieval History, 31 (2005), pp. 342-43.

${ }^{159}$ S. Epstein, An Island for Itself: Economic Development and Social Change in Late Medieval Sicily (Cambridge, 1992), chp. 4.

${ }^{160}$ C. Higounet, Paysages et villages neufs d'Aquitaine (Bordeaux, 1975), pp. 417-38; R. Germain, "Les migrations comme facteur d'équilibre démographique (Bourbonnais XIVe-XVe siècles)," in Population et démographie au Moyen Age (Paris, 1995), pp. 251-66; A. Higounet-Nadal, Perpignan aux XIV et XV siècles. Etude de démographique historique (Bordeaux, 1978).

${ }^{161}$ D. Tys and M. Pieters, "Understand a Medieval Fishing Settlement along the Southern Northern Sea: Walraversijde, c. 1200-1630," in L. Sicking and D. Abreu-Ferreira (eds.), Beyond the Catch: Fisheries of the North Atlantic, the North Sea and the Baltic, 900-1850 (Leiden, 2009), pp. 91-122; H. Fox, The Evolution of the Fishing Village: Landscape and Society along the South Devon Coast, 10861550 (Leicester, 2001).

${ }^{162}$ D. Curtis, "Florence and its Hinterlands in the Late Middle Ages: Contrasting Fortunes in the Tuscan Countryside, 1300-1500," Journal of Medieval History 38 (2012), pp. 472-99.

${ }^{163}$ S. Oosthuizen, "Cambridgeshire and the Peat Fen: Medieval Rural Settlements and Commerce, c. AD 900-1300," in Christie and Stamper (eds.), Medieval Rural Settlement, pp. 206-24. 
Often urban demand had an impact on the countryside, with many new small concentrated settlements springing up across Western Europe as rural market centres and trading posts grew in number during the high Middle Ages ${ }^{164}$ Commercial influences from London had a significant impact on settlement development in the rural hinterlands. ${ }^{165}$ Sometimes powerful sectional and group interests shaped this process. ${ }^{166}$ Lords often granted explicit privileges to certain settlements in the hope of stimulating the economy of market centres, and profiting from the trade in turn. ${ }^{167}$ Some concentrated settlements expanded into small towns as a result of their status as compulsory trading venues for their hinterlands. ${ }^{168}$ In the south of France, lords even created bastides with the prime intention of securing a reservoir of taxes on all trade performed at the market. ${ }^{169}$ They served the function of regulating and stabilising traffic in food and textile produce. ${ }^{170} \mathrm{In}$ Lombardy, the weak position of territorial lords such as the Sforza in the mid fifteenth century led eventually to jurisdictional autonomy for a number of new rural communities, which subsequently formed their settlements around markets. ${ }^{171}$ In effect, people began

${ }^{164}$ R. Britnell, “The Proliferation of Markets in England, 1200-1349," Economic History Review, 34 (1981), pp. 209-21; T. Lalik, "Märkte des 12. Jahrhunderts in Polen," Kwartalnik Historii Kultury Materialnej, 10 (1962), p. 364; A. Jones and J-L. Kupper, "Villes, bourgs et franchises en Wallonie de 1250 à 1477," in H. Hasquin (ed.), La Wallonie. Le pays et les hommes (Brussels, 1982), I, p. 145; C. de la Roncière, Florence: centre économique régional au XIVe siècle (Aix-en-Provence, 1976), III, pp. 951-1013; P. Toubert, "Les statuts communaux et l'histoire des campagnes lombardes au XIVe siècle," Mélanges d'Archéologie et d'Histoire, 72 (1960), p. 499. On village centres of exchange and their role in meeting the needs of the peasant population, see :G. Duby, Early Growth of the European Economy (London, 1974), pp. 162-80.

${ }^{165}$ M. Gardiner, "South-East England: Forms and Diversity in Medieval Rural Settlement," in Christie and Stamper (eds.), Medieval Rural Settlement, p. 114.

${ }^{166}$ S. Epstein, "Regional Fairs, Institutional Innovation, and Economic Growth in Late Medieval Europe," Economic History Review, 47 (1994), p. 462. Also see C. Dyer, "The Consumer and the Market in the Late Middle Ages," Economic History Review, 42 (1989), pp. 305-27.

${ }^{167}$ R. Goddard, "Small Boroughs and the Manorial Economy: Enterprise Zones or Urban Failures?," Past and Present, 210 (2011), pp. 3-31; C. Taylor, "Medieval Market Grants and Village Morphology," Landscape History, 4 (1982), pp. 21-28.

${ }_{168}$ R. Rutte, Stedenpolitiek en stadsplanning in de Lage Landen (12de-13 de eeuw) (Zutphen, 2002), pp. $125-27$.

${ }^{169}$ See the classics; C. Higounet, Les Villeneuves de Piémont et les bastides de Gascogne (XIIXIVe siècles) (Paris, 1970), pp. 130-39; Nouvelle approche sur les bastides du Sud-Ouest aquitain (Paris, 1967), pp. 32-35.

${ }^{170}$ Many of these areas were built with clear grid or circular ("circulades") plans, and it has been suggested quite recently by scholars that the largest of medieval rural settlements were often inspired by towns founded earlier in the Middle Ages. See C. Higounet, "Les origines et la foundation de la bastide de Vianne (1284)," Revue de l'Agenais (1984), pp. 5-24; K. Pawloski, "Villes et villages circulaire du Languedoc," Annales du Midi, 9 (1987), pp. 407-28; C. Cyer and K. Lilley, "Town and Countryside, Relationsips and Resembalnces," in Christie and Stamper (eds.), Medieval Rural Settlement, pp. 81-98.

${ }^{171}$ G. Chittolini, "I capitoli di dedizione delle comunità lombarde a Francesco Sforza: motivi di contrasto fra città e contado," in Felix olim Lombardia: studi di storia padana in onore di G. Martini (Milan, 1978), pp. 673-93; "Governo ducale e poteri locali," in Gli Sforza a Milano e in Lombardia e i loro rapporti con gli stati italiani ed europei (1450-1535) (Milan, 1982), pp. 27-42; "Legislazione statutaria e autonomie nella pianura bergamasca," in M. Cortesi (ed.), Statuti rurali e statuti di valle. La provincia di Bergamo nei secoli XIII-XVIII (Bergamo, 1984), pp. 93-114. 
to congregate around village squares, greens, or piazze, in a growing culture of barter and trade, ${ }^{172}$ and some of these central trading areas can still be recognized even today. ${ }^{173}$

One of the limitations of this framework is that while commercialization may have stimulated the growth of new market centres, around which rural people began increasingly to congregate, it also may explain the complete break-down of coherent villages. One of the consequences of commercialization in late-medieval Western Europe was land consolidation and accumulation. ${ }^{174}$ Thus, for example, urban expropriation of rural property-holders in the late-medieval Florentine contado, coupled with harsh fiscal oppression and the imposition of the onerous demands of mezzadria (sharecropping), led to mass migration from the countryside into Florence. ${ }^{175}$ As a result, village settlements collapsed and farm plots were abandoned. ${ }^{176}$ The rural poor eventually populated the impoverished suburbs of Florence, often to the south and the east. ${ }^{177}$ A similar trend can be seen in many of the city-states of Northern Italy in the transition from the late Middle Ages to the early modern period as the urban expropriation of peasant lands became a general phenomenon. ${ }^{178}$ Commons were encroached upon. ${ }^{179}$ In Lombardy, 57 percent of the land in the Cremonese contado was owned by burghers of Cremona (and that

${ }^{172}$ C. Higounet, “Congregare populationem: politiques de peuplement dans l'Europe méridionale (Xe-XIVe siècles),” Annales de Démographie Historique (1979), pp. 135-44.

${ }^{173}$ As in parts of Tuscany; G. Cherubini and R. Francovich, "Forme e vicende degli insediamenti nella campagna Toscana nei secoli xii-xv," Quaderni Storici, 24 (1973), p. 875.

${ }^{174}$ D. Curtis, "The Impact of Land Accumulation and Consolidation on Population Trends in the Pre-Industrial Period: Two Contrasting Cases in the Low Countries," Historical Research (2014), forthcoming.

${ }^{175}$ M. Nenci, "Ricerche sull'immigrazione dal contado alla città di Firenze nella seconda metà del XIII secolo," Studi e Ricerche, 1 (1981), pp. 139-77; W. Day Jr., "Population Growth and Productivity: Rural-Urban Migration and the Expansion of the Manufacturing Sector in Thirteenth-Century Florence," in B. Blondé, M. Galand, and E. Vanhaute (eds.), Labour and Labour Markets between Town and Countryside (Middle Ages-19th Century) (Turnhout, 2001), pp. 82-110.

${ }^{176}$ D. Herlihy, "Santa Maria Impruneta: A Rural Commune in the Late Middle Ages," in N. Rubinstein (ed.), Florentine Studies: Politics and Society in Renaissance Florence (London, 1968), pp. 242-76; C. Klapisch-Zuber, "Villaggi abbandonati ed emigrazioni interne," in R. Romano and C. Vivanti (eds.), Storia d'Italia: i documenti (Turin, 1973), V, pp. 311-69; C. Klapisch-Zuber and J. Day, "Villages désertés en Italie: esquisse," in R. Romano and P. Courbin (eds.), Villages désertés et histoire économique: XI-XVIII siècle (Paris, 1965), pp. 437-38, 442-43.

${ }^{177}$ E. Faini, "Da Bagno a Ripoli a Firenze (e ritorno)," in P. Pirillo (ed.), Alle porte di Firenze: il territorio di Bagno a Ripoli in età medievale (Rome, 2008), pp. 41-56; "L'emigrazione dal Valdarno Superiore a Firenze nel XII secolo: una storia mancata," in P. Pirillo and M. Ronzani (eds.), Storie di una pieve del Valdarno. San Romolo a Gaville in età medievale (Rome, 2008), pp. 105-21.

${ }^{178}$ An overview of urban land accumulation in G. Cherubini, "La proprietà fondiaria nei secoli XV-XVI nella storiografia italiana," Società e Storia, 1 (1978), pp. 9-33.

${ }^{179}$ L. Chiappa Mauri, "Riflessioni sulle campagne lombarde del Quattro-Cinquecento," Nuova Rivista Storica, 69 (1985), p. 129; G. Panjek, "Beni comunali: note storiche e proposte di ricerca," in A. Tagliaferri (ed.), Venezia e la Terraferma attraverso le relazioni dei Rettori (Milan, 1981), pp. 371 82; R. Rao, "Risorse collettive e tensioni giurisdizionali nella pianura vercellese e novarese (XII-XIII secolo)," Quaderni Storici, 120 (2005), pp. 753-76; "Lo spazio del conflitto. I beni comunali nel Piemonte del basso Medioevo," Zapruder, 11 (2006), pp. 8-25. 
excludes urban ecclesiastical institutions), while in the Venetian terraferma, urban citizens owned between one-half to two-thirds of the land. ${ }^{180}$ A similarly high proportion of the land was controlled by urban interest groups in the late-medieval territories of Parma, Piacenza, and in particular, Bologna. ${ }^{181}$ As a result, newly proletarianized rural-dwellers had little option but to migrate to the various cities and towns. In fact, it has been shown that in tougher economic periods, the swarm of rural people upon the cities in search of work and food was so great that many urban governments closed their gates to keep out beggars and vagrants. ${ }^{182}$

Of course, widespread rural-urban migration put more pressure on those who decided to remain in the countryside, as peasant assistance in the maintenance of complex hydraulic works completely unravelled. ${ }^{183}$ The consequence was increased susceptibility to flooding, which in turn caused a vicious cycle of outward migration and rural settlement collapse. In that sense, although commercialization may have stimulated the development of new concentrated rural settlements in the high and late Middle Ages, this process was not inevitable. Indeed, the exact same level of commercialization in other areas brought about the opposite trend - a contraction and sometimes even collapse of the settlement structures.

\section{Conclusion}

Three key points can be taken from this historiographical review of research on the emergence of concentrated settlements in Western Europe. They pertain respectively to the periodization of settlement concentration; to "agents" during settlement change; and to the intensity and speed of settlement formation.

Approaches that have emphasized "power and coercion" and the "arrangement of field systems" have been extremely influential in explaining settlement concentration in medieval Western Europe. However, recent research has shown the limitations of both frameworks to be broadly similar. One of the key issues is chronology. Concentrated settlements are now being found all across Western Europe prior to the great phase of formalized seigneurialism (roughly beginning from the tenth century). Similarly the concentration of settlement is also being found in certain places prior to open-field formation (which in itself has a highly divergent chronological development). To some extent at issue is the definition we give to

${ }^{180}$ S. Epstein, "The Peasantries of Italy," in T. Scott (ed.), The Peasantries of Europe from the Fourteenth to the Eighteenth Centuries (London, 1998), p. 89. On late-medieval urban land acquisition in the terraferma of Venice see G. Gullino, "Quando il mercante costrui la villa: le proprietà dei Veneziani nella Terraferma," in Storia di Venezia. Dal Rinascimento al Barocco (Rome, 1994), IV, pp. $875-$ 924; D. Beltrami, La penetrazione economica dei veneziani in Terraferma. Forze di lavoro e proprietà fondiaria nella campagne venete dei secoli XVII e XVIII (Venice, 1961).

${ }^{181}$ L. Arcangeli, "Giurisdizioni feudali e organizzazione territoriale nel Ducato di Parma (15451587)," in M. Romani (ed.), Le corti farnesiane di Parma e Piacenza, 1543-1622 (Rome, 1978), I, p. 97; G. Chittolini, La formazione dello stato regionale e le istituzioni del contado (Turin, 1979), pp. 261-65.

${ }^{182}$ J. Gutton, La société et les pauvres en Europe, XVIe-XVIIIe siècles (Paris, 1974), pp. 104-6.

${ }^{183}$ Curtis and Campopiano, "Medieval Land Reclamation." 
the term "concentrated settlement" and the distinctions we might draw between it and a term such as "village." I have intentionally defined "concentrated settlement" very broadly, bearing in mind that different degrees of settlement concentration developed over time. Settlement concentration occurred in many regions of Western Europe before the emergence of incastellamento. That is not to diminish the importance of incastellamento in certain areas: the fortification process may have simply intensified processes already taking place. The same goes for the emergence of the open fields. The loose clustering of people into concentrated habitations may have occurred in some places before the development of the open fields, but that is not to deny the eventual importance of these last. The field rearrangement process may have likewise intensified processes which were already in their incipient stages. Alternatively, open fields may have entirely disrupted the settlement pattern and led to newly located and arranged concentrated settlements.

This issue of the "degree" of settlement concentration is an important one. Indeed, it is this point that explains why the four explanatory frameworks have not and should not be presented in opposition to one another. In fact the divergent agents, periodization, and speed of the settlement concentration process across regions of medieval Western Europe demonstrate that the process was incremental and uneven. Frameworks for settlement concentration across Western Europe thus only make sense with proper regard for period, geography, and social context. It is possible that all four of the explanatory frameworks outlined here could apply to a given settlement at different points in its development. To be sure, the frameworks are interchangeable and overlapping. The open fields may have led to the emergence of new concentrated settlements, but these open fields may have been devised and laid down through powerful and dominant interest groups. Territorial formation and the formalization of communalism at the local level may have led settlements to crystallize, but this apparently bottom-up process could easily have been a response to the growing power and sharpness of seigneurial jurisdictions. The recasting of fields may have led to the reorganization of settlement in some places, but this may have been a process already linked to increased urban demand and commercialization: peasants either wishing to produce more or to protect themselves from the market (depending on one's interpretation of the function of the open fields). Indeed, the principal frameworks for understanding the formation of medieval concentrated settlements are mutually reinforcing and, perhaps most significantly, cannot be viewed in isolation from one another.

Daniel R. Curtis received his $\mathrm{PhD}$ from Utrecht University. His first book is to appear in Ashgate's "Rural Worlds" series in 2014 under the title Coping with Crisis: The Resilience and Vulnerability of Pre-Industrial Settlements. At the moment he is funded by a British Academy (Leverhulme) Small Research Grant, and is currently working on a project reconstructing aspects of household structure, marriage patterns, and levels of domestic service in Southern Italy during the long eighteenth century. 